Amasya İlahiyat Dergisi - Amasya Theology Journal

ISSN 2667-7326 | e-ISSN 2667-6710

Haziran / June 2020, 14: 9-50

\title{
Halvetiyye Geleneğindeki Nefis Mertebeleri Anlayışının \\ Hadislerdeki Dayanakları \\ (Yusuf Sünbül Sinân'ın Etvâr-ı Seb`a Risâlesi Özelinde)
}

\author{
The Hadith-Based Foundations of the Nafs Stages in Khalwatiyya \\ Tradition \\ (In the example of al-Atwar al-Sab'a Epistle Written by Yusuf Sunbul \\ Sinan)

\section{Muammer BAYRAKTUTAR} \\ Doç. Dr., Tokat Gaziosmanpaşa Üniversitesi, İslami İlimler Fakültesi, \\ Hadis Anabilim Dalı \\ Associate Professor, Tokat Gaziosmanpaşa University, \\ Faculty of of Islamic Sciences, Department of Hadith \\ Tokat, Turkey \\ muammer.bayraktutar@gop.edu.tr \\ orcid.org/0000-0003-0814-0529
}

\section{Makale Bilgisi / Article Information}

Makale Türü / Article Types: Araştırma Makalesi / Research Article

Geliş Tarihi / Received: 30 Ocak / January 2020

Kabul Tarihi / Accepted: 17 Nisan / April 2020

Yayın Tarihi / Published: 30 Haziran / June 2020

Yayın Sezonu / Pub. Date Season: Haziran / June

Say1 / Issue: 14 Sayfa / Pages: 9-50

Atıf / Cite as: Bayraktutar, Muammer. "Halvetiyye Geleneğindeki Nefis Mertebeleri Anlayışının Hadislerdeki Dayanakları (Yusuf Sünbül Sinân'ın Etvâr-ı Seb'a Risâlesi Özelinde) [The Hadith-Based Foundations of the Nafs Stages in Khalwatiyya Tradition (In the example of al-Atwar al-Sab'a Epistle Written by Yusuf Sunbul Sinan)]". Amasya Illahiyat Dergisi-Amasya Theology Journal 14 (June 2020): 9-50.

https://doi.org/10.18498/amailad.682262. 
10 I M. BAYRAKTUTAR / Halvetiyye Geleneğindeki Nefis Mertebeleri Anlayışının Hadislerdeki Dayanakları (Yusuf Sünbül Sinân'ın Etvâr-ı Seb 'a Risâlesi Özelinde)

İntihal / Plagiarism: Bu makale, en az iki hakem tarafından incelendi ve intihal içermediği teyit edildi. / This article has been reviewed by at least two referees and scanned via a plagiarism software.

Copyright $\odot$ Published by Amasya Üniversitesi, İlahiyat Fakültesi / Amasya University, Faculty of Theology, Amasya, 05100 Turkey. All rights reserved. https://dergipark.org.tr/amailad.

\section{The Hadith-Based Foundations of the Nafs Stages in Khalwatiyya Tradition (In the example of al-Atwar al-Sab'a Epistle Written by Yusuf Sunbul Sinan)}

\section{Abstract}

Sünbül Sinan, who was born in Merzifon/Amasya/Turkey and the founder of Sünbüliyye branch of Khalwatiyya tradition, is one of the important sûfî figures in the period of Ottoman Empire. He is a supporter of the arguments about dance and fortune in the Ottoman era. In this regard, he published several works. His another publication is Risala fi Bayan al-Atwar al-Sab 'a. He addresses the hirarchies of sayr-u suluk in this epistle. The conception of al-Atwar al-Sab'a (seven stages) has also an important place in Khalwatiyya and there are epistles written on this issue. One of these epistles is Sunbul Efendi's epistle. When discussing and explaining the subject, he used both Quran verses and hadiths. The hadith understanding and utilizing of sûfis is different than the understanding of hadith narrators. Sûfis sometimes might not behave mildly when finding narratives that approve their teachings and understandings. In this paper, we address, discuss, and analyze the content of this epistle, the hadith understanding of sûfîs, and the hadiths that Sunbul Efendi used to ground his understanding of atwar sab'a, and thereby, we aim to determine if the statements considered as hadiths in the epistle are real or not. Additionally, we aim to assess the certainty, indication, and meaning of the statements considered as evidence and hadith in detail regarding the understanding of atwar al-sab'a, it is aimed to contribute to the studies in the field of hadith and mysticism.

\section{Summary}

Sunbul Sinan Efendi (d. 936/1529), who was born in Amasya / Merzifon and was the founder of the Sunbuliyye branch of the Khalwatiyya tradition, is one of the essential Sufistic personalities of the Ottoman period. He is a leading supporter of the Sufi dance (raqs) and Sufi whirling (dawran) discussions in the Ottoman period. In addition to the works he has been copyrighted in this 
M. BAYRAKTUTAR / The Hadith-Based Foundations of the Nafs Stages in Khalwatiyya Tradition (In the example of al-Atwar al-Sab'a Epistle Written by Yusuf Sunbul Sinan) | 11 subject, one of his essential works is Risala fî Bayan al-Atwar al-Sab'a. In this epistle of Sunbul Efendi, he discusses sayr and suluk (path) in Sufism. The understanding of al-Atwar al-Sab'a (seven stages) also has an essential place in the Khalwatis, and epistles concerning this issue were written. The epistle of Sunbul Efendi is one of them.

Sunbul Sinan has given place more verses and hadiths in grounding his nafs stages in his epistles compared to other atwar authors. In his epistle, Sunbul Sinân gave 16 narrations or words he cited as a hadith and referred to as evidence and a basis to justify the order of suluks. As a result of the detections, deductions, and criticisms of the hadith, words, and narrations, among them there are 1 authentic, 1 hasan li ghairihi, 3 weak hadiths in terms of imputation, and the remaining 11 narrations or words consists of words and observations, some of which are not initially hadith, some of which are regarded as fabricated, and some are not involved in the sources. Besides, it is observed that the vast majority of these narrations in the epistle did not exist in the first period hadith and Sufism sources, mostly in the classified and copyrighted sources in the later periods, and some of them were not involved in the sources at all. Hence, it is probable to say that in the early periods, some of the people who are ascetic (zahid), Sufi, and wise, or words that were supposed to have the correct meaning of different cultures and personalities, were reflected in the sources of the next period and conveyed to Sufism by transforming them into hadith. In this regard, a more in-depth research is required on the source of narrations that are effective in Sufism and used as hadith and their conveyance to Sufism.

Sufi's hadith understanding and use of hadith may change from the hadith understanding of the narrator of hadiths. At this point, Sufis can sometimes present a moderate behavior when it comes to narrations that verify their teachings and understanding. Sunbul Sinan's attitude is observed to be similar to the Sufi approach concerning hadith if the use of hadith in epistles and understanding of hadith in general. The author has adopted an approach in presenting the hadiths as evidence, not more than the correctness and certitude of the hadith, but he cares about whether his meaning is relevant in terms of verifying and explaining his teachings.

Sunbul Sinan also made ishari (implied) comments on the words and narrations he presented as hadith. Still, in his ishari interpretations, he abided by the rules inquired in the ishari interpretation, did not eliminate the apparent meaning of the hadiths, nor did he make any interpretations contradicting to the general 
12 I M. BAYRAKTUTAR / Halvetiyye Geleneğindeki Nefis Mertebeleri Anlayışının Hadislerdeki Dayanakları (Yusuf Sünbül Sinân'ın Etvâr-ı Seb 'a Risâlesi Özelinde)

principles of religion. He sought to ground his nafs hierarchies based on the lafz or ishari meaning of the narrations and words he presented as evidence. Still, it is seen that the naqli (prophecy) evidence given in this subject as hadith are not based on a reliable basis, especially in hadith, and that almost all of them are comprised of weak, unreliable, controversial and problematic words and news. Still, by examining the status of the narrations presented in this epistles, it is not right to reach a conclusion and opinion that there is no religious and scientific basis in the understanding that expresses the nafs stages in the Sufism, or the course of perfection of man as the al-atwar al-sab'a. Because the primary goal of the Qur'an and Sunnah is to enhance man morally, to acquit his nafs, to glorify his soul, and bring it to perfection in the world and the heaven. The primary purpose of Sufism is to help and guide people in fulfilling this goal. It is recognized that Sunbul Sinan, like the Sufis, adopted this aim as a basis in the use of hadith. Sufis gave importance to every word that complied with the purposes of Sufism and whose meaning was relevant in terms of their own teachings and exhibited a lenient attitude for equating the unreliable narrations, criticized in terms of correctness and certitude, as hadith of the Prophet. Still, at this point, it will unquestionably be a more suitable approach for the Sufis to consider the methods and principles of the hadith, and to act with an understanding that prefers correct and consistent narrations rather than problematic narrations in terms of correctness and certitude while grounding the doctrine and understanding of Sufism. Because in the context of verifying the teachings of Sufism, there are adequate verses and correct hadiths, and their correctness does not create a need for problematic narrations. Consequently, the understanding of al-atwar al-sab' $a$, which has an essential place in sayr and suluk, should be based on the Qur'an and Sunnah axis, by reconsidering the methods and data of the hadith, in the context of more reliable narrations in terms of correctness and certitude. Such new research and studies may create a decrease in the criticisms that will be aimed towards Sufism and will also add to grow and enhance the Sufism understanding based on solid foundations within the context of the Qur'an and Sunnah. As a result, in the article, the nature of his epistle, as well as the understanding of hadiths, the hadiths used by Sunbul Efendi to ground the understanding of al-atwar al-sab'a were evaluated in terms of deduction, criticism, and analysis within the context of hadith science, and the real value of the words presented as hadith in the epistle was sought to put forward. 
In the meantime, it was aimed to evaluate the suitability of the hadiths and words presented as evidence to ground the understanding of al-atwar al-sab'a in terms of certitude, implication, and meaning, and to contribute to the studies in the field of hadith and Sufi sciences.

Keywords: Hadith, Sufism, Khalwatiyya, Sunbul Sinan, al-Atwar al-Sab'a.

\section{Halvetiyye Geleneğindeki Nefis Mertebeleri Anlayışının Hadislerdeki Dayanakları \\ (Yusuf Sünbül Sinân'ın Etvâr-ı Seb`a Risâlesi Özelinde)}

\section{Öz}

Amasya/Merzifon'da doğan ve Halvetiyye tarikatının Sünbüliyye kolunun kurucusu olan Sünbül Sinân Efendi (ö. 936/1529), Osmanlı döneminin önemli tasavvufi şahsiyetlerinden biridir. Osmanlı döneminde yaşanan raks ve devran tartışmalarının önde gelen taraftarlarındandır. Bu hususta eserler telif etmiştir. Telif ettiği önemli eserlerinden biri de Risâle fî Beyâni'l-Etvârı's-Seb'a isimli eseridir. Sünbül Efendi bu risâlesinde tasavvufta seyr-ü sülûk mertebelerini konu edinmektedir. Etvar-1 seb'a (yedi evre) anlayışı aynı zamanda Halvetîlerde önemli bir yere sahip olup bu hususta risaleler kaleme alınmıştır. $\mathrm{Bu}$ risalelerden biri de Sünbül Efendi'nin söz konusu risâlesidir. Sünbül Efendi konuyu izah ederken ve ele alırken âyetlerin yanısıra hadislere de yer vermiştir. Sûfîlerin hadis anlayışı ve hadis kullanımı, muhaddislerin hadis anlayışından farlılıklar arz edebilmektedir. Sûfîler bu noktada bazen öğretilerini ve anlayışlarını teyid eden rivayetler söz konusu olduğunda mütesahil davranabilmektedirler. Makalede risâlesinin mahiyeti, sûfîlerin hadis anlayışının yanısıra, Sünbül Efendi'nin Etvâr-ı Seb'a anlayışını temellendirirken kullandığı hadisler, tahric, tenkid ve tahlil yönleriyle hadis ilmi açısından incelenmiş ve risâlede hadis olarak ifade edilen sözlerin, gerçek değeri ortaya konulmaya çalışılmıştır. Bu arada delil olarak sunulan ve hadis olarak ifade edilen sözlerin etvar-1 seb'a anlayışının temellendirilmesine sübut, delâlet ve anlam olarak uygunluğu değerlendirilmeye çalışılmış, hadis ve tasavvuf ilimleri sahasındaki çalışmalara katkı sunması amaçlanmıştır.

Anahtar Kelimeler: Hadis, Tasavvuf, Halvetiyye, Sünbül Sinân, Etvâr-1 Seb`a.

\section{Giriş}

Bir dini bilgi ve uygulamanın meşrû ve muteber olmasında Kur'an ve Sünnet'e uygunluk temel bir kriter olup, meşruiyetini bu iki 
14 I M. BAYRAKTUTAR / Halvetiyye Geleneğindeki Nefis Mertebeleri Anlayışının Hadislerdeki Dayanakları (Yusuf Sünbül Sinân'ın Etvâr-ı Seb 'a Risâlesi Özelinde)

kaynaktan almayan hiçbir dini bilgi ve öğreti makbul görülmemiştir. İslam tasavvufu da temelde Kur'an ve Sünnet'e dayanan, insanın kemâle ulaşmasını gaye edinen, kendine özgü öğretileri bulunan bir ilimdir. Tarihi süreçte zühd ve tasavvuf hareketinde kurumsallaşmalar ve buna bağlı olarak insanın olgunlaşmasına dair farklı usul ve anlayışlar ortaya çıkmıştır. Bunlardan biri de sülûk mertebeleri diye bilinen nefis mertebeleri/etvâr-1 seb'a anlayışıdır. Sûfî âlimler nefis mertebelerini temellendirirken âyet ve hadislerden deliller getirerek dayanaklarını ortaya koymaya çalışmışlardır. Bu sûfî âlimlerden biri de Yusûf Sünbül Sinân'dır (ö. 936/1529). Çalışmada Sünbül Sinân'ın etvâr-1 seb'a anlayışını temellendirme bağlamında risâlesinde delil olarak sunduğu hadislerin/rivayetlerin tespit, tahric, tenkid ve değerlendirilmesi yapılarak, farklı disiplinlerin verileri de dikkate alınmak suretiyle hadis ilmi açısından değeri makale boyutu çerçevesinde ortaya konulmaya çalışılmıştır.

\section{Sünbül Sinân'ın Hayatı ve İlmî Şahsiyeti}

Osmanlı döneminin meşhur Halvetî şeyhlerinden Sünbül Sinân Efendi'nin asıl adı Yusuf b. Yakûb olup, Amasya'nın Merzifon kazasında doğmuştur. Merzifon'daki ilk tahsilinden sonra önce Isparta'da, akabinde İstanbul'da medrese tahsilini tamamlamıştır. Sünbül Sinân, Halvetî şeyhi Cemal Çelebî’ye (ö. 899/1494) intisap ederek tasavvuf yoluna girmiş, seyru sülûkunu tamamladıktan sonra, Koca Mustafa Paşa Dergahının postnişini olmuş, vefatına kadar irşad faaliyetlerini devam ettirmiştir. Halvetiyye tarikatının Sünbüliyye kolunun kurucusudur. Sünbül Sinân, II. Bayezid, Yavuz Sultan Selim ve Kanunî Sultan Süleyman dönemlerini idrak etmiş, 936/1529 yılında vefat etmiştir. Cenaze namazı şeyhu'l-islâm İbn Kemâl (ö. 940/1534) tarafından Fatih Camii'nde kıldırılarak dergâhının hazîresine defnedilmiştir. ${ }^{1}$ Sünbül Sinân aralarında Şeyh Merkez Muslihuddin

1 Hayatı hakkında bk. Osmanzâde Hüseyin Vassâf, Sefine-i Evliyâ, haz. Mehmet Akkuş - Ali Yılmaz (İstanbul: Kitabevi Yayınları, 2015), 3/363-393; Bursalı Mehmed Tahir, Osmanlı Müellifleri, haz. A. Fikri Yavuz - İsmail Özen (İstanbul: Meral Yayınevi, ts.), 1/179-180; Hür Mahmut Yücer, "Sünbül Sinân", Türkiye Diyanet Vakfı İslam Ansiklopedisi (Ankara: TDV Yayınları, 2010), 38/135-136; Mehmet Şirin Ayiş, "Sünbül Sinân'ın İlmî ve Tasavvufî Kişiliği", Uluslararası Amasya Âlimleri Sempozyumu (Amasya: Kıbatek, 2017), 1/647-655; Mehmet Kalayc1, “Kadizâdeliler-Halvetîler Geriliminin Odağında Bir İsim: Sünbül Sinân el-Amâsî ve er-Risâletü't-Tahkîkiyye 
M. BAYRAKTUTAR / The Hadith-Based Foundations of the Nafs Stages in Khalwatiyya Tradition (In the example of al-Atwar al-Sab'a Epistle Written by Yusuf Sunbul Sinan) I 15

Efendi'nin (ö. 959/1551-52) de bulunduğu pek çok halife yetiştirmiş, ${ }^{2}$ vefatı üzerine postuna Merkez Efendi oturmuştur. ${ }^{3}$

\section{Tasavvufta Etvâr-1 Seb'a Anlayışı ve Sünbül Sinân Efendi'nin “Etvar-1 Seb'a" Risâlesi}

Tasavvufta etvâr-1 seb'a, nefsin emmâre, levvâme, mülhime, mutmainne, râzıye, marziyye ve kâmileden oluşan yedi mertebesini ifade etmek amacıyla kullanılan bir kavramdır. ${ }^{4}$ Tavr kelimesinin çoğul hali olan etvâr; hal, evre, aşama, merhale, mertebe gibi anlamalara gelmektedir. Tasavvuf ilminde "etvâr" kelimesi zamanla manevî hayatın gelişim basamaklarını ifade eden teknik bir terime dönüşmüş ve bu basamaklar sûfîlerin anlayışında yedi mertebe olarak kabul edildiğinden, yedi rakamı ilâve edilerek "etvâr-1 seb'a" olarak ifadelendirilmiştir. ${ }^{5}$ Nefsin mertebelerinin her biri Kur'an'daki âyetlerden mülhem olarak isimlendirilmiştir. ${ }^{6}$ Etvâr-1 seb'a kavramı, tarikatların uygulama usullerinin şekillendiği XII. asırdan itibaren tasavvuf literatüründe yer almaya başlamıştır.7 Etvâr-1 seb'a anlayışı, tasavvufun temel amaciyla doğrudan ilgili bir konudur. Tasavvuf, insanın süflî yaşamdan ulvî yaşama evrilerek olgunlaşması yönüyle etvar-1 seb'a anlayışı ile gaye bakımından ortaktır. Nitekim Sünbül Sinân'ın mensup olduğu Halvetîlik geleneği, benliğin yedi evrede kemâl mertebesine ulaştı̆̆1 anlayışı üzerine kuruludur ve bu anlayış 'etvâr-1 seb'a'/yedi evre tâbiriyle ifade edilmektedir. ${ }^{8}$ Nitekim Cemal Halvetî, insanın yedi tavır üzere üzere yaratıldığı görüşünü, insanın anne

Adlı Eseri", Uluslararası Amasya Âlimleri Sempozyumu (Amasya: Kıbatek, 2017), 1/602; Emrehan Küey, “Merkez Efendi ve Sünbül Sinân”, Bursa'da Dünden Bugüne Tasavvuf Kültürü-3, haz. H. Basri Öcalan (Bursa: Bursa Kültür Sanat Vakfı Yayınları, 2014), 185-195.

2 Ayiş, “Sünbül Sinân'ın İlmî ve Tasavvufî Kişiliğì", 1/652.

3 Küey, “Merkez Efendi ve Sümbül Sinân”, 188.

4 Süleyman Uludağ, "Nefis", Türkiye Diyanet Vakfı İslam Ansiklopedisi (İstanbul: TDV Yayınları, 2006), 32/528.

5 İbrahim Işıtan, "Halvetiyye Geleneğine ve Bir Halvetiyye Şeyhi Olan Sofyalı Bâlî Efendi'ye Göre Sülûkün Yedi Evresi (Atvâr-1 Seb’a)”, Hikmet Yurdu 4/7 (2011), 91.

6 Osman Türer, Tasavvuf Tarihi (İstanbul: Seha Neşriyat, ts.), 135.

7 Ali Haydar Bostancı, Tasavvuf'ta Etvâr-1 Seb'a ve Sofyalı Bâlî Efendi'nin "Etvâr-1 Seb`a"sı (İstanbul: Marmara Üniversitesi, Sosyal Bilimler Enstitüsü, Yüksek Lisans Tezi, 1996), 26-27.

8 Işıtan, "Bâlî Efendi'ye Göre Sülûkün Yedi Evresi", 90. 
16 I M. BAYRAKTUTAR / Halvetiyye Geleneğindeki Nefis Mertebeleri Anlayışının Hadislerdeki Dayanakları (Yusuf Sünbül Sinân'ın Etvâr-ı Seb ‘a Risâlesi Özelinde)

karnında yedi aşamada yaratıldığı âyeti ${ }^{9}$ ile "Sizi tavırlarla yarattık." (Nûh, 71/14) âyetine dayandırmıştır. ${ }^{10}$ Sünbül Sinan ise etvar-1 seb 'a'yı bu âyetin yanısıra hadislerle de temellendirmiştir. ${ }^{11}$

Halvetiyye geleneğinde etvâr-1 seb'a konusunda pek çok risâle kaleme alınmıştır. ${ }^{12}$ Bunlardan biri de Sünbül Sinân'ın Etvar-ı Seb 'a risâlesidir. Çalışmada Sünbül Sinân Efendi'nin Milli Kütüphane Yazmalar Koleksiyonunda kayıtlı Arapça nüshası esas alınmıştır. Risâlenin tam adı eserin baş tarafında Risaletün Şerifetün fî Beyâni Etvâri's-Seb'a fî Tarîki't-Tasavouf ve'z-Zühd şeklinde yer almaktadır. ${ }^{13}$ Sünbül Efendi risâlesinde ihtisar yoluyla insanın kalb evrelerini yazacağını, taliplilerin zabtının ve hıfzının kolay olması için tafsilata girmeyeceğini ifade etmektedir. Sünbül Sinan nefsin yedi mertebesini önce tasavvufî açıdan izah ettikten sonra her bir mertebeyi bir peygamber ve gezegen ismi ile açıklayarak, nefis mertebelerine yeni bir yaklaşım ve yorum getirmiştir. ${ }^{14}$ Risâle hakkında birtakım çalışmalar bulunmakla birlikte, ${ }^{15}$ risâledeki hadislerin değerlendirilmesine yönelik herhangi bir çalışma bulunmamaktadır.

9 el-Mü'minûn, 23/12-14.

10 Mehmet Serhan Tayşî, "Cemâl-i Halvetî”, Türkiye Diyanet Vakfı İslam Ansiklopedisi (İstanbul: TDV Yayınları, 1993), 7/302.

11 Sinân, Etvâr-ı Seb'a, 15b.

12 Halvetiyye geleneğinde aralarında Sünbül Sinân'ında bulunduğu farklı halvetî şeyhleri tarafından yazılan on dokuz etvar-1 seb'a risâlesi Fatih Yıldız tarafından bir kitapta toplanarak yayımlanmıştır. Bk. Fatih Yıldız, Halvetî Azizlerinin Etvâr-ı Seb’a Risâleleri (İstanbul: Büyüyenay Yayınları, 2019).

13 Sünbül Sinân Yusuf b. Hüsâm el-Amâsî, Rîsâle-i Beyân-ı Etvâr-ı Seb'a (Risaletun Şerifetun fî Beyâni Etvâri's-Seb'a fì Tarîki't-Tasavvuf ve'z-Zuhd), Milli Kütüphane Yazmalar Koleksiyonu, DVD No: 1788, Arşiv No: 06 Mil Yz A8942/2, vr. 11a-19a (yeni vr. no:14a-22a).

14 Sünbül Sinan'ın Etvâr risalesi hakkında geniş bilgi için bk. Mehmet Şirin Ayiş, "Sünbül Sinân ve Atvâr-1 Seb’a Risalesi Bağlamında Nefis Mertebeleri", Bingöl Üniversitesi Sosyal Bilimler Enstitüsü Dergisi 7/13 (2017), 121.

15 Ayiş, "Sünbül Sinân ve Atvâr-1 Seb’a Risalesi Bağlamında Nefis Mertebeleri", 119138. Risâle'nin Türkçe çevirisi için bk. Yıldız, "Yusuf Sünbül Sinân Etvâr-1 Seb'â", Halvetî Azizlerinin Etvâr-ı Seb`a Risâleleri (İstanbul: Büyüyenay Yayınları, 2019), 169187. 
M. BAYRAKTUTAR / The Hadith-Based Foundations of the Nafs Stages in Khalwatiyya Tradition (In the example of al-Atwar al-Sab'a Epistle Written by Yusuf Sunbul Sinan) I 17

\section{Sünbül Sinân'ın Etvâr-1 Seb'a Risâlesindeki Hadislerin Değerlendirilmesi}

Tasavvufta nefis mertebeleri anlayışının genel olarak hadislerdeki dayanaklarının ortaya konulması, araştırılması gereken bir önemi haizdir. Sünbül Sinân nefis mertebeleri/etvâr-ı seb'a anlayışını birtakım âyetlerle, hadis diye ifade ettiği birtakım rivayet ve sözlerle temellendirmiştir. Çalışmada risaledeki hadis ve rivayetlerin tahric ve tenkid yapılarak, hadis ve rivayetlerin müellifin etvar-1 seb'a anlayışı bağlamında kendi öğretileri için delil olmadaki uygunluğuna dair değerlendirmelerde bulunulmuştur. Şimdi bu hadisleri değerlendirmeye geçelim.

\section{1. “Ben her ne kadar sûret olarak Âdem'in oğlu olsam da, onda benim babalığıma şahitlik eden benden bir mana vardır."}

Sünbül Sinân Efendi, risâlesine başlarken ifade ettiği görüşlere göre; Allah Teâlâ Âdem'i halife olarak yaratmış, onu kendi güzelliği için hazine ve ayna kılmış, kemâlinin güzelliğini izhar etmek istediğinde de, onu onda ispat etmek için Muhammed (as)'in nurûnu (Nûr-i Muhammedî) yaratmıştır. Sonunda bütün eşyâ/varlıklar, gaybdan ayna misâli ona yansıyarak vücuda gelmiştir. Böylece Muhammed (sas), ebu'l-ervâh/ruhların babası ve ümmü'l-eşyâ/varlıkların anası olmuştur. Sünbül Sinân akabinde Nûr-i Muhammedî anlayışını temellendirmek üzere Peygamber (sas)'in şöyle buyurduğunu ifade etmektedir: إنّ وإن كُنْ Ben her ne kadar sûret olarak Âdem'ın oğlu olsam da, onda benim babalığıma şahitlik eden benden bir mana vardır." 16

Müellifin Nûr-i Muhammedî anlayışını temellendirmek amacıyla yer verdiği bu sözün Hz. Peygamber'e âidiyetine dâir herhangi bir bilgi ve kayıt yoktur. Bu söz Hz. Peygamber'in dilinden sâdır olmuş gibi, İbnu'l-Fârız (ö. 632/1235) tarafından Divân'ında bir beyit olarak ifade edilmiştir. ${ }^{17}$ Sonra gelen âlimler İbnu'l-Fârız' in sözü olarak ona nispet

16 Sinân, Etvâr-ı seb'a, 14 a. Ayrıca bk. Yıldız, "Yusuf Sünbül Sinân Etvâr-ı Seb'â", 169. Hz. Peygamber'in kainatın yaratılış sebebi olduğunu, Âdem henüz su ve çamur arasındayken onun peygamberliğini ve âlemin Muhammed'in nurundan yaratıldığını ifade eden rivayetlerin değerlendirilmesi için bk. Bünyamin Erul, "Uydurma Rivâyetlerde Peygamber Tasavvuru", İslâm'ın Anlaşılmasında Sünnetin Yeri ve Değeri Sempozyumu (Ankara: TDV Yayınları, 2001), 420-422.

17 İbnu'l-Fârız Şerefuddîn Ömer, Dîvânu İbni'l-Fârız (Beyrut: Dâru Sâdır, ts.), 105. 
18 I M. BAYRAKTUTAR / Halvetiyye Geleneğindeki Nefis Mertebeleri Anlayışının Hadislerdeki Dayanakları (Yusuf Sünbül Sinân'ın Etvâr-ı Seb 'a Risâlesi Özelinde)

etmişler ve Nûr-1 Muhammedî’yi temellendirmek üzere kullanmışlardır. Nitekim müfessir Âlûsî (ö. 1270/1854) bunlardan biri olup, âyetlerin işârî yorumu bağlamında Nûr-1 Muhammedî'yi temellendirirken İbnu'lFârız'ın sözüne de yer vermiştir. ${ }^{18}$ Dolayısıyla Sünbül Sinân $\mathrm{Hz}$. Peygamber'den sâbit olmayan bir söze dayanarak Nûr-1 Muhammedî anlayışını temellendirmeye çalışmıştır. İlk dönem sûfilerinde Nûr-1 Muhammedî anlayışı bulunmamakta olup, hicrî üçüncü asırdan itibaren tasavvufta yer almaya başlayan bir anlayıştır. ${ }^{19}$ Sünbül Sinan da, tasavvufta yer alan Nur-ı Muhammedî anlayışını sürdüren sûfîlerden biridir.

\section{2. "Önce Refîk, Sonra Tarîk"}

Sünbül Sinân manevî yolculukta nefis mertebelerini aşma konusunda sâlike bir mürşidin/rehberin gerekliliğini ifade ederken "Eğer bilmiyorsanız, zikir ehline/bilenlere sorun." (el-A'râf 7/180) âyetine, sonra da Hz. Peygamber'in الرفيق ثم الطريق/Önce yol arkadaş1 (refîk), sonra yol (tarîk)" hadisine yer vermektedir. O bu yolda talibe klavuzluk edecek mürşidi ve rehberi ehl-i telkin olarak nitelendirmekte, ${ }^{20}$ kemâl yolunda salîke eşlik edecek bir mürşidin gerekliliğini ilgili âyet ve hadisle temellendirmektedir.

Hadis kaynaklarına bakıldığında rivayetin الرفيق ثم الطريق şeklindeki lafzından ziyade, benzer anlamda biraz daha farklı lafızlarla yer aldığ1 görülmektedir. Nitekim İbn Ebû Hayseme (ö. 279/892) tarafından Rafî b. Hadîc isnadiyla Hz. Peygamber'den merfû olarak "Ev satın almadan önce komşu, yoldan önce yol arkadaşı arayınız" şeklinde rivayet edilmiştir. ${ }^{21}$ Hadis benzer lafızlarla Taberânî (ö. 360/971), ${ }^{22}$ Ebu'ş-Şeyh (ö. 369/979), ${ }^{23}$ Kudâî (ö. 454/1062) ${ }^{24}$ ve Hatîb Bağdadî (ö. 463/1071) ${ }^{25}$

18 Şihâbuddîn Mahmûd el-Âlûsî, Rûhu'l-maânî, thk. Ali Abdulbârî Atryye (Beyrut: Dâru'l-kutubi'l-ilmiyye, 1415), 1/220, 2/419, 8/520, 13/59, 15/129.

19 Ahmet Yıldırım, Hoca Ahmed Yesevî'nin Hadis Kültürü (Ankara: TDV Yayınları, 2012), 133.

20 Sinân, Etvâr-ı seb'a, 14 b.

21 Ebû Bekr Ahmed b. Ebî Hayseme, et-Târîhu'l-kebîr, thk. Salâh b. Fethî (Kahire: elFâruku'l-Hadîse, 1425/2006), 2/705.

22 Suleyman b. Ahmed et-Taberânî, el-Mu'cemu'l-kebîr, thk. Hamdî Abdulmecîd (Kahire: Mektebetu İbn Teymiyye, 1415/1993), 4/268.

23 Abdullah b. Muhammed Ebu'ş-Şeyh, Emsâlu'l-hadîs, thk. Abdulalî Abdulhamîd (Bombay: ed-Dâru's-Selefiyye, 1408/1987), 273. 
M. BAYRAKTUTAR / The Hadith-Based Foundations of the Nafs Stages in Khalwatiyya Tradition (In the example of al-Atwar al-Sab'a Epistle Written by Yusuf Sunbul Sinan) I 19

tarafından da kaydedilmiştir. Hz. Alî’den nakledilen rivayete göre ise Hz. Peygamber (sas): “Evden önce komşu, yoldan önce yol arkadaşı الرَّيق binekten önce azık gerekir" buyurmuştur. ${ }^{26}$ Bazı kaynaklarda ise Hufâf b. Nüdbe (ra)'ye Hz. Peygamber'in “Ey Hufâf! Yoldan önce yol arkadaşı edin" diye tavsiyede bulunduğu nakledilmektedir. ${ }^{27}$ Dulâbî'nin (ö. 310/923) kaydettiği rivayette ise Osman b. Atâ tarafından babasının sözü olarak nakledildiği görülmektedir. ${ }^{28}$

Şu halde hadisin merfû olarak Hz. Ali ve Rafî b. Hadîc isnadiyla iki ayrı tarikten nakledildiği görülmektedir. Hz. Ali'nin rivayeti, Rafî b. Hadic'in rivayeti için şahid olarak değerlendirilmiştir. Hadis münekkitlerine göre, Hz. Ali ve Rafî b. Hadîc'den iki ayrı tarikten merfû olarak nakledilen rivayetin isnadları ise zayıftır. Hadisin, birbirlerini takviye ile hasen li-gayrihi derecesine yükseleceğini ifade edenler de vardır. ${ }^{29}$ Ancak hadisin temel hadis kaynaklarında rivayet edilmediği, ilk olarak h. III. asırda İbn Ebî Hayseme tarafından kaydedildiği, ama daha çok hicrî IV. asırdan sonra tasnif edilen kaynaklarda yer aldığı görülmektedir.

24 Muhammed b. Selâme el-Kudâî, Musnedu'ş-şihâb, thk. Hamdî Abdulmecîd (Beyrut: Muessesetu'r-Risâle, 1407/1986), 1/412.

25 Ahmed b. Alî el-Hatîb el-Bağdâdî, el-Câmi' li-ahlâki'r-râvî, thk. Mahmûd Tahhân (Riyâd: Mektebetu'l-Maârif, 1403/1983), 2/233.

26 Hatîb, el-Câmi' li-ahlâki'r-râvî, 2/232; Şîrûyeh b. Şehrdâr ed-Deylemî, el-Firdevs bime'sûri'l-hitâb, thk. es-Saîd b. Besyûnî (Beyrut: Dâru'l-kutubi'l-ilmiyye, 1406/1986), 2/119.

27 Muhammed b. el-Huseyn el-Ezdî, el-Mahzûn fî ilmi'l-hadîs, thk. M. İkbal Muhammed (Delhi: ed-Dâru'l-ilmiyye, 1408/1988), 80; Hatîb, el-Câmi' li-ahlâki'r-râvî, 2/235.

28 Muhammed b. Ahmed ed-Dûlâbî, el-Kunâ ve'l-esmâ, thk. Muhammed el-Faryâbî (Beyrut: Dâru İbn Hazm, 1421/2000), 3/953.

29 Şemsuddîn Muhammed ez-Zehebî, Mîzânu'l-i'tidâl, thk. A. Muhammed el-Bicâvî (Beyrut: Dâru'l-Ma'rife, 1382/1963), 1/15, 2/159; Bedruddîn Muhammed ez-Zerkeşî, el-Leâliu'l-mensûra fi'l-ehâdîsi'l-meşhûra, thk. M. Abdulkadir Atâ (Beyrut: Dâru'lkutubi'l-ilmiyye, 1406/1986), 120; Ahmed b. Ali b. Hacer el-Askalânî, Lisânu'l-Mizân, thk. Abdulfettâh Ebû Gudde (b.y.: Dâru'l-Beşâiri'l-İslâmiyye, 2002), 1/228, 4/75; Şemsuddîn Muhammed es-Sehâvî, el-Makâsıdu'l-hasene, thk. M. Osmân el-Hişt (Beyrut: Dâru'1-Kutubi'1-Arabî, 1405/1985), 151-152; Celâluddîn Abdurrahman esSuyûtî, ed-Dureru'l-muntesira fi'l-ehâdîsi'l-muştehira, thk. M. Lutfi es-Sabbâğ (Riyad: Câmiatu'l-Melik Suud, ts.), 101; İsmail b. Muhammed el-Aclûnî, Keşfu'l-hafâ (Kahire: Mektebetu'l-Kudsî, 1351), 1/179, 321. 
20 I M. BAYRAKTUTAR / Halvetiyye Geleneğindeki Nefis Mertebeleri Anlayışının Hadislerdeki Dayanakları (Yusuf Sünbül Sinân'ın Etvâr-ı Seb ‘a Risâlesi Özelinde)

Hadisin zahiri anlamına bakıldığında yola çıkmadan önce, yol arkadaşı edinmenin önemine işaret edildiği anlaşılmaktadır. Nitekim Hz. Peygamber'in tek başına yola çıkmayı tavsiye etmediği rivayet edilmiştir. ${ }^{30}$ Zâhid ve sûfîler ise hadisi sadece dünyevî yolculuklar için değil, manevî yolculuk olarak addedilen seyr-u sülûk yolunda da arkadaş, mürşid/rehber edinmenin gerektiği hususunda delil olarak kullanmışlardır. Hadis her ne kadar isnad itibariyle zayıf olsa da bu anlamda kullanılmasında bir beis bulunmadığını söylemek mümkündür.

\section{3. “Küfür ve İman Arş’ın Gerisinde İki Makamdır”}

Sünbül Efendi risâlesinde Hz. Peygamber'in الكفر ولإيمان مقامان ما وراء العرش" "Küfür ve iman Arş'ın ötesinde iki makamdır" buyurduğunu ifade etmektedir. ${ }^{31}$

Sünbül Efendi'ye göre, Arş'a kadar birtakım perdeler bulunmakta olup, iman ve küfür de esasen Allah ile kul arasında birer perdedir. Bu perdelerden biri zulmânî/kahrânî iken diğeri nurânî/lutfânîdir. Bütün perdeler bu iki perdenin fer'idir/dallarıdır. ${ }^{32}$ Müellif bu görüşünü ise bir sonra ele alacağımız hadise dayandırmaktadır. Ancak Hz. Peygamber'in "Küfür ve iman Arş'ın ötesinde iki makamdır" şeklinde bir hadisi tespit edilemediği gibi, kaynaklarda Hz. Peygamber dışında yine herhangi birine nispet edilen böyle bir söze rastlanılamamıştır. Bu bakımdan bu sözün, hadis olarak kabulü mümkün gözükmemektedir.

\section{Vardır."}

\section{4. “Allah ile Kul Arasında Nur ve Zulmetten Yetmiş Bin Perde}

Sünbül Efendi'nin belirttiğine göre Nebî (sas) şöyle buyurmuştur: "Şüphesiz Allah ile kul arasında nur ve zulmetten yetmiş bin perde vardır."

30 Muhammed b. İsmâîl el-Buhârî, el-Câmiu's-sahîh, thk. M. Zuheyr b. Nâsır (b.y.: Dâru tavkı'n-necât, 1422), "Cihâd”, 135. Ayrica bk. Suleymân b. el-Eş'as es-Sicistânî, Sunen, thk. M. Muhyiddîn Abdulhamîd (Beyrut: el-Mektebetu'l-Asriyye, 1430/2009), "Cihâd", 79; Muhammed b. İsâ et-Tirmizî̀, Sunen, thk. Beşşâr Avvâd (Beyrut: Dâru'lGarbi'l-İslâmî, 1998), "Cihâd", 4; Muhammed b. Yezîd Mâce, Sunen, thk. Şuayb elArnaût - Kâmil Karabellî (b.y.: Dâru'r-Risâle, 1430/2009), "Edeb”, 45.

31 Sinân, Etvâr-ı seb'a, 15 a. a

32 Sinân, Etvâr-ı seb'a, 15 a.

33 Sinân Etvâr-ı seb'a, 15 b. 
M. BAYRAKTUTAR / The Hadith-Based Foundations of the Nafs Stages in Khalwatiyya Tradition (In the example of al-Atwar al-Sab'a Epistle Written by Yusuf Sunbul Sinan) I 21

Müellifin hadisin devamında ifade ettiğine göre bu yetmiş bin perdenin on bini zulmânî olup bu perdeler zahirî hükümler ve zahiri zühd ile aşılır. Altmış bin perde ise nurânîdir ve bunları aşmak da ancak onların başlangıcına ve sonuna vâkıf olan bir kimseye tabi olmakla mümkün olur. $\mathrm{O}$ da sülûkteki mertebesi, seyr an'illah, yani yedinci mertebede (tavr-1 sâbi ${ }^{`}$ ) olan kimsedir. ${ }^{34}$ Müellif, Allah ile kul arasındaki perdeleri aşmanın, sülûk mertebelerini kat etmekle mümkün olduğunu yetmiş bin perde rivayetiyle temellendirmektedir.

Müellifin kaynak zikretmeksizin Hz. Peygamber'e nispet ettiği yetmiş bin perde hadisinin temeli, bazı hadis kaynaklarında yer alan benzer anlamlı rivayetler olduğu anlaşılmaktadır. Nitekim senedinde Musa b. Ubeyde er-Rebezî' nin yer aldığı bir rivayette Hz. Peygamber' in şöyle buyurduğu nakledilmiştir: "Şüphesiz ki Allah (cc), nur ve zulmetten yetmiş bin perdenin ardındadır. Bu perdelere herhangi bir nefis, ses duyacak kadar yaklaşırsa yanar." 35

Hatîb el-Bağdâdî'nin kaydettiği ve senedinde Habîb b. Ebî Habîb'in bulunduğu bir isnadla Sehl b. Sa'd'dan naklettiği bir rivayete göre ise Hz. Peygamber "Şüphesiz Allah ile yaratılanlar arasında yetmiş bin perde vardır" 36 buyurmuştur. İbnü'l-Cevzî (ö. 597/1201) “hadisin aslı yoktur" demiş, ravilerinden Musa b. Ubeyde hakkında Ahmed b. Hanbel'in "benim nazarımda ondan rivayet caiz değildir", Yahya b. Maîn'in "leyse bi-şey" şeklinde değerlendirmede bulunduğunu belirtmiştir. ${ }^{37}$ İbnu'l-Cevzî'ye göre hicabla ilgili hadisler genellikle zayıf

34 Sinân, Etvôr-ı seb'a, 15 b.

35 Taberânî, el-Mu'cemu'l-kebîr, 6/148, 8/411. Diğer kaynaklar için bk. İbn Ebî Âsım Ahmed b. Amr, Kitâbu's-sunne (b.y.: el-Mektebu'l-İslâmî, 1400/1980), 2/366; Ebû Ya'lâ Ahmed b. Alî. Musnedu Ebî Ya'lâ, thk. H. Selîm Esed (Dımaşk: Dâru'l-Me'mûn, 1404/1984), 13/520; Muhammed b. Hârûn er-Rûyânî, Musnedu'r-R̂yyânî, thk. Eymen Alî (Kahire: Muessesetu Kurtuba, 1416), 2/212; Abdullah b. Muhammed Ebu'ş-Şeyh, Kitâbu'l-azame, thk. Rıdâullah b. Muhammed (Riyâd: Dâru'l-Âsıme, 1408), 2/667; Muhammed b. İshâk el-Kelâbâzî, Bahru'l-fevâid, thk. Muhammed Hasen - Ahmed Ferîd (Beyrut: Dâru'l-kutubi'l-ilmiyye, 1420/1999), 264; Ahmed b. el-Huseyn elBeyhakî, el-Esmâ ve's-slfât, thk. A. Muhammed el-Hâşidî (Cidde: Mektebetu's-Sevadî, 1413/1993), 2/292.

36 Hatîb Bağdâdî, Mûdıhu evhâmi'l-cem ve't-tefrîk, thk. A. Emîn Kal'acî (Beyrut: Dâru'1Ma'rife, 1407), 2/16.

37 Cemâluddîn Abdurrahman el-Cevzî, el-Mevzûât, thk. A. Muhammed Muhsin (Medîne: el-Mektebetu's-Selefiyye, 1388/1968), 1/116. 
22 I M. BAYRAKTUTAR / Halvetiyye Geleneğindeki Nefis Mertebeleri Anlayışının Hadislerdeki Dayanakları (Yusuf Sünbül Sinân'ın Etvâr-ı Seb ‘a Risâlesi Özelinde)

ve metruk olan, sika olmayan raviler tarafından nakledilmiş sözlerden ibarettir. Bu sebeple hicab/perde rivayetlerini aslı olmamakla ve mevzû olmakla nitelendirilmiştir. ${ }^{38}$

Suyutî (ö. 911/1505) ise Musa b. Ubeyde ve Habîb b. Ebî Habîb'in hadis uydurmakla değil, zayıf (vâhî) olmakla itham edildiğini, rivayetin şahit ve mütabîlerinin hadisin aslı olduğuna delalet ettiğini belirtmektedir. ${ }^{39}$ İbn Arrâk da (ö. 963/1556) hadisin sihhat ve subutu hakkında Suyûtî̀ye benzer değerlendirmelerde bulunmuş, Zehebî'nin de (ö. 748/1348) bu durumda rivayet hakkındaki hükmün mevzû'dan vâhî’ye dönüşeceğini ifade ettiğini belirtmiştir.40 İbn Hacer de (ö. 852/1449) rivayetin isnadını zayıf olarak değerlendirmiştir. ${ }^{41}$

Ebu Saîd ed-Dârimî (ö. 280/894) ise Zurâre b. Evfâ'nın mürsel olarak rivayet ettiği hadise göre Hz. Peygamber, Cebrail'e "Rabbini gördün mü?" diye sormuş, bunun üzerine Cebrail irkilmiş ve şöyle cevap vermiştir: “Ey Muhammed! Şüphesiz O'nunla benim aramda nurdan yetmiş perde vardır. Eğer onun en yakın olanına yaklaşsam, yanardım." ${ }^{42}$ Hadis mürsel olarak rivayet edildiği için isnadı zayıf kabul edilmiştir. Hicabla ilgili hadislere Ebû Saîd ed-Dârimî'nin toplu olarak ilk olarak yer veren musanniflerden olduğu anlaşılmaktadır. ${ }^{43}$ Cebrail'in verdiği cevapla ilgili rivayet sonraki kaynaklarda Enes'den merfû tarzda

38 İbnu'l-Cevzî, el-Mevzûat, 1/116-117; Suyûtî, el-Leâliu'l-masnûa (Beyrut: Dâru'lkutubi'l-ilmiyye, 1414/1996), 1/21; Muhammed b. Alî eş-Şevkânî, el-Fevâidu'l-mecmûa, thk. Abdurrahman el-Muallimî (Riyad: Dâru'l-kutubi'l-ilmiyye, ts.), 42; Nâsıruddîn el-Elbânî, Silsiletu'l-ehâdisi'z-zaîfe ve'l-mevzûa (Beyrut: Dâru'l-Maârif, 1412/1992), 14/67. Allah ile kullar arasındaki perdelerden bahsedilen hicab hadisleri/rivayetleri tarafımızdan daha geniş olarak çalışılmakta olup yayımlanması planlanmaktadır.

39 Suyûtî, el-Leâliu'l-masnûa, 1/21

40 Ebu'l-Hasen Nûruddîn b. Arrâk, Tenzîhu'ş-şerîa, thk. Abdulvahhâb Abdullatif Sıddık el-Gumârî (Beyrut: Dâru'l-kutubi'l-ilmiyye, 1399), 1/142.

41 İbn Hacer el-Askalânî, İthâfu'l-hıyereti'l-mehere, thk. Ebû Temîm Yâsir (Riyad: Dâru'lvatan, 1420/1999), 1/187, 6/166; İbn Hacer el-Askalânî, el-Metâlibu'l-âliye (Riyad: Dâru'l-Âsıme, 1420/2000), 12/576, 14/197. Ayrıca bk. İbn Ebî Âsım, Kitâbu's-sunne, $2 / 367$.

42 Osman b. Saîd ed-Dârimî, er-Red ala'l-Cehmiyye, thk. Bedr b. Abdullah (Kuveyt: Dâru İbni'l-Esîr, 1416/1995), 73. Dârimî'nin rivayetinde yetmiş bin yerine, yetmiş perde ifadesi yer almaktadır.

43 Dârimî, er-Red ala'l-Cehmiyye, 71-73. 
M. BAYRAKTUTAR / The Hadith-Based Foundations of the Nafs Stages in Khalwatiyya Tradition (In the example of al-Atwar al-Sab'a Epistle Written by Yusuf Sunbul Sinan) I 23 da rivayet edilmiştir. ${ }^{44}$ Zehebî ise bu rivayeti münker olarak değerlendirmiştir. ${ }^{45}$

İbn Huzeyme (ö. 311/924) ise yetmiş bin veya yetmiş perdenin bulunduğundan bahseden maktû rivayetlere yer vermektedir. ${ }^{46} \mathrm{Ebu}^{\prime}$ şŞeyh'in (ö. 369/979) Kitâbu'l-azame adlı eserinde ise yetmiş bin perde rivayetleri yine mevkûf ve maktû olarak da Abdulllah b. Amr, Abdullah b. Ömer ve Mücahid'den nakledilmiştir. ${ }^{47}$ Ebu'ş-Şeyh ayrıca Vehb b. Münebbih'in Tevrat'a dayandirarak Allah'in perdelerinden ve aralarındaki yıl olarak miktarlarından bahseden çok detaylı rivayetlere yer vermiştir. ${ }^{48}$

Derviş el-Hût (ö. 1276/1860) ise yetmiş bin perdeyle ilgili Hz. Peygamber'den sabit olan bir hadisin bulunmadığını, ancak Müslim'in Sahîh'inde nakledilen şu rivayetin bulunduğunu belirtmektedir. ${ }^{49}$ Ebu Musa el-Eş'arî’nin naklettiğine göre Peygamber (sas): “O'nun hicabı nurdur. Eğer onu açacak olsa, Zâtının nurları (subuhât) bütün varlıkları yakard1"50 buyurmuştur. Kur'an'da ise Allah'ın bir beşer ile konuşmasından bahsedilirken "perde arkasından" ifadesi kullanılmıştır. ${ }^{11}$ Sonuç olarak Kütüb-i tis'a kapsamındaki temel hadis

44 İbnu'l-A'râbî Ahmed b. Muhammed, Mu'cemu İbni'l-A'râbî, thk. Abdulmuhsin elHuseynî (Suûdiyye: Dâru İbni'l-Cevzî, 1418/1998), 2/468; Suleyman b. Ahmed etTaberânî, el-Mu'cemu'l-evsat, thk. Tarık Ivadullah - Abdulmuhsin b. İbrahim (Kahire: Dâru'l-Harameyn, ts.), 6/278; Ebu'ş-Şeyh, Kitabu'l-azame, 2/669; Ebû Nuaym, Hilyetu'l-evliyâ, 5/55.

45 Şemsuddîn Muhammed ez-Zehebî, Siyeru a'lâmi'n-nubelâ (Kahire: Dâru'l-Hadîs, 1427/2006), 6/354.

46 Muhammed b. İshâk b. Huzeyme, Kitâbu't-teohîd, thk. Abdulazîz b. İbrahim (Riyâd: Mektebetu'r-Ruşd, 1414/1994), 1/50-51.

47 Ebu'ş-Şeyh, Kitâbu'l-azame, 2/667-724.

48 Ebu'ş-Şeyh, Kitâbu'l-azame, 2/706-708, 710, 711.

49 Muhammed Dervîş el-Hût, Esne'l-metâlib, thk. M. Abdulkâdir Atâ (Beyrut: Dâru'lkutubi'l-ilmiyye, 1418/1997), 127.

50 Ebu'l-Huseyn Muslim b. el-Haccâc, el-Musnedu's-sahîh, thk. M. Fuâd Abdulbâkî (Beyrut: Dâru İhyâi't-Turâsi'l-Arabî, ts.), “İman”, 293. Ayrıca bk. Suleymân b. Dâvud et-Tayâlisî, Musned, thk. M. Abdulmuhsin et-Turkî (Misır: Dâru Hicr, 1419/1999), 1/395; Ahmed b. Muhammed b. Hanbel, el-Musned, thk. Şuayb el-Arnaût - Âdil Murşid (Beyrut: Muessesetu'r-Risâle, 1421/2001), 32/357, 404; İbn Mâce, "İman", 13; Ahmed b. Amr el-Bezzâr, Musned, thk. Mahfûzurrahman Zeynullah vd. (Medîne: Mektebetu'l-ulûm, 2009), 8/36.

51 eş-Şûrâ, 42/51. 
24 I M. BAYRAKTUTAR / Halvetiyye Geleneğindeki Nefis Mertebeleri Anlayışının Hadislerdeki Dayanakları (Yusuf Sünbül Sinân'ın Etvâr-ı Seb ‘a Risâlesi Özelinde)

kaynaklarından yetmiş veya yetmiş bin perdeden bahseden herhangi bir hadis ve rivâyet bulunmamaktadır. Şu halde tespitlerimize göre yetmiş perde ifadesiyle ilgili ilk rivayetin ilk kez Osman ed-Dârimî'nin eserinde, yetmiş bin perde rivayetinin ise İbn Ebî Âsım (ö. 287/900) ve Taberânî gibi hadisçilerin eserlerinde yer aldığı ve zayıf olmaktan pek öteye geçemediği görülmektedir. Dolayısıyla bu verilere göre yetmiş bin perde ifadeli söz ve rivayetleri Hz. Peygamber'e ait makbul birer hadis olarak değerlendirmek mümkün gözükmemektedir.

Tasavvuf erbabı, sâlikle Hak arasında bulunan ve O'nu bilmeye (marifet) engel teşkil eden herşeyi hicâb/nikâb (perde) olarak nitelendirmiş ve bunlardan yakınmışlardır. ${ }^{52}$ Tasavvufta Allah'a ulaşma yolunda sâlikin önünde engel teşkil eden perdeleri ortadan kaldırmak amacıyla yedi mertebe anlayışı geliştirilmiştir. Nitekim Halvetîlik geleneğinde de seyr-u sülûk'ta takip edilen yedi esmanın her birinin yetmiş bin perdesi bulunduğu, Kahhâr esmâsını tamamlayarak, en sonunda nefs-i kâmile mertebesine ulaşan sâlike yetmiş bin perdenin açılacağ ${ }_{1}$ anlayışı bulunmaktadır. ${ }^{53}$ Müellifin kendi tarikat geleneğinine binâen, sülûk mertebeleri arasinda perdeler bulunduğunu temellendirmek amacıyla yetmiş bin perde rivayetine atıf yaptığ anlaşılmaktadır.

\section{5. "Yedi Uzuv Üzerine Secde Etmekle Emrolundum."}

Sünbül Sinân, sülûkun yedi mertebe olduğu ifade eden etvar-1 seb'a anlayışını temellendirme bağlamında Hz. Peygamber'in امرت أن أسجد "Yedi uzuv üzerine secde etmekle emrolundum" hadisini delil olarak getirmektedir. ${ }^{54}$

Hadis başta Buhârî (ö. 256/870) olmak üzere temel hadis kaynaklarında rivayet edilmiştir. ${ }^{55}$ Buhârî'nin rivâyetine göre $\mathrm{Hz}$. Peygamber (sas) "Ben alın -bu esnada burnunu da işaret etmiştir- iki el, iki diz, iki ayak uçları olmak üzere yedi kemik/organ üzerine secde

52 Sufîlerin perde anlayışı hakkında geniş bilgi için bk. Süleyman Ateş, "Hicâb”, Türkiye Diyanet Vakfı İslam Ansiklopedisi (İstanbul: TDV Yayınları, 1998), 17/431.

53 Ateş, "Hicâb", 17/431.

54 Sinân, Etvâr-ı seb'a, 15 b.

55 Bu husustaki rivayetler için bk. Tirmizî, "Salât", 203; Ahmed b. Şuayb en-Nesâî, Sunen, thk. Abdulfettâh Ebû Gudde (Haleb: Mektebetu'l-Matbûâti'l-İslâmiyye, 1406/1986), "Tatbîk", 39. 
etmekle emrolundum" buyurmuştur. ${ }^{56}$ Hadisin zâhiri, namazda hangi organlar üzerine secde edilmesi gerektiğini ifade ederken, müellif tarafından hadisteki yedi ifadesinden hareketle, seyr-u sülûkun de yedi mertebesi olduğuna bir dayanak olarak kullanılmış ve hadisteki bu anlamin "ehl-i butûn arasında zâhir/açı olduğunu" ifade ederek ${ }^{57}$ hadisi tasavvufî ve işârî manada yorumlamıştır.

\section{6. “Ey Âdemoğlu, Kalbinden Dünya Sevgisini Çıkar.”}

Sünbül Sinân, sülûkun birinci mertebesi (tavr-1 evvel) olan nefs-i emmâre makamını izah ederken nefsin kötülüğü emrettiğini, ruhun nefsin elinde esir olduğunu, âhireti hatırlamadığını ve Mevlâ'nın muhabbetine engel olan dünyayı sevdiğini ifade bağlamında şu kudsî

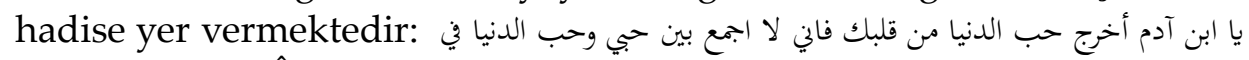
"Ey Âdemoğlu, kalbinden dünya sevgisini çıkar. Zira ben bir kalpte benim sevgimle dünya sevgisini asla birarada bulundurmam." 58 Müellif devamında "Çünkü bu ikisi birbirine zıttır. Zıtlar da bir arada bulunmaz" diyerek nefis makamı olan birinci mertebede kişinin Allah sevgisine mani olan dünyevî isteklerin ve nefsanî arzularının perde oluşunu bu sözle temellendirmeye çalışmaktadır.

Kaynaklarda tam bu lafızla bir rivayet tespit edilmemiştir. Ancak buna benzer şu rivayetler vardır: Meselâ İbnü'l-Cüneyd el-Huttelî (ö. 270/884) her hangi bir sened zikretmeksizin "bize ulaştığına göre" (belağanâ) ifadesini kullanarak Allah Teâlâ'nın Hz. Dâvud'a şöyle vahyettiğini nakletmektedir: “Ey Davud! Beni sevdiğini mi iddia ediyorsun? Eğer beni seversen, dünya sevgisini kalbinden sök at. Zira benim sevgimle onun sevgisi bir kalpte birarada olmaz." ${ }^{59} \mathrm{Bu}$ sözü ilk olarak nakleden Huttelî́dir. Huttelî́nin aynı zamanda dönemin sûfilerinden, eserinin de tasavvuf alanında tasnif edilen ilk eserlerden biri olması itibariyle ${ }^{60}$ Sünbül Sinân'ın bu sözü bu tür kaynaklardan almış olması ihtimalini güçlendirmektedir. Bazı kaynaklarda ise Ebû Cafer el-Basrî́nin "Allah Teâlâ, Hz. Davud'a şöyle vahyetti." şeklindeki

\footnotetext{
56 Buhârî, "Sifatu's-salât", 52, 53.

57 Sinân, Etvâr-ı seb'a, 15 b.

58 Sinân, Etvâr-ı seb'a, 15 b.

59 İbrahim b. Abdullah el-Huttelî, el-Muhabbetu lillâhi Subhânehu, thk. Abdullah Bedrân (Dımaşk: Dâru'l-Mektebî, 1423/2000), 39.

60 Cemil Akpınar, "Huttelî", Türkiye Diyanet Vakfı İslâm Ansiklopedisi (İstanbul: TDV Yayınları, 1998), 18/429.
} 
26 I M. BAYRAKTUTAR / Halvetiyye Geleneğindeki Nefis Mertebeleri Anlayışının Hadislerdeki Dayanakları (Yusuf Sünbül Sinân'ın Etvâr-ı Seb ‘a Risâlesi Özelinde)

sözlerine yer verilmiştir. ${ }^{61}$ Dolayısıyla ilgili sözün merfû, mevkûf ve maktû şeklinde isnadlı herhangi bir rivayeti bulunmamaktadır. Sonuç olarak bu söz, her ne kadar zühd ve Allah sevgisi açısından tasavvufun temel öğretileriyle uyumlu olsa da hadis olarak değerlendirmek mümkün gözükmemektedir.

\section{7. “Varlığın Hiçbir Günahla Mukayese Edilemeyecek Bir Günahtır."}

Müellif sülûk mertebelerinin üçüncüsü (tavr-1 sâlis) olan nefs-i

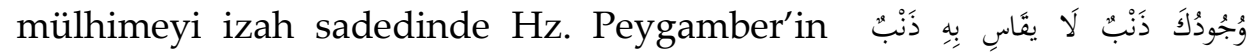
"Senin (hakka engel olan) varlığın /benliğin öyle bir günahtır ki, hiçbir günah onunla mukayese edilemez" buyurduğuna yer vermektedir. ${ }^{62}$ Ona göre bu mertebe makâm-1 ruh ve mülhime olup, sâlik bu evrede Allah'a aşkla bağlanır. Bu mertebede aşk bazı sâliklere galebe çalıp aklını alır ve "ene'l-hakk" davasında bulunur. Bu mertebede sâlike ilim ve irfan hasıl olur, hakka mani olan varlığı/benliği fani/zâil olmuş olur. ${ }^{63}$ Sünbül Efendi işte bu bağlamda benliğin esasında Hakk'a engel olan bir günah olduğunu $\mathrm{Hz}$. Peygamber'e nispet ettiği sözle temellendirmektedir.

Müellif tarafından hadis olarak Hz. Peygamber'e nispet edilmiş olsa da, kaynaklarda bu rivayet hadis olarak nakledilmemiştir. Bazı kaynaklarda Hz. Peygamber'e nispet edilmeksizin "denildi ki" lafzıyla yer verilmiştir. ${ }^{4}$ Bazı kaynaklarda ise bir beytin bir misraı olarak yer almaktadır. ${ }^{65} \mathrm{Bu}$ yüzden bu sözün $\mathrm{Hz}$. Peygamber'in bir hadisi olduğunu söylemek mümkün gözükmemektedir.

61 Mubârek b. Abdulcebbâr et-Tuyûrî, et-Tuyûriyyât, thk. Abbas Sahr (Riyâd: Mektebetu Edvâi's-Selef, 1425/2004), 3/1038; Ebû Hâmid Muhammed el-Gazzâlî, İhyâu ulûmi'ddîn (Beyrut: Dâru'l-Ma'rife, ts.), 4/326; İsmâil b. Muhammed et-Teymî, et-Tergîb ve'tterhîb, thk. Eymen b. Sâlih (Kahire: Dâru'l-Hadîs, 1414/1993), 2/245; Muhammed b. Mukrim b. Manzûr, Muhtasaru Târîhi Dımaşk li-İbn Asâkir (Dımaşk: Dâru'l-Fikr, 1402/1984), 8/121.

62 Sinân, Etvôr-ı seb'a, 18 a.

63 Sinân, Etvâr-ı seb'a, 18 a.

64 Nûreddîn Alî el-Kârî, Mirkâtu'l-mefâtîh (Beyrut: Dâru'l-fikr, 1422/2002), 2/673, 4/1340, 8/3822; İsmail Hakk1 Bursevî, Rûhu'l-beyân (Beyrut: Dâru'l-Fikr, ts.), 1/333, 2/197, 220, 6/454, 8/508, 9/386; Âlûsî, Rûhu'l-maânî, 9/202, 13/237; Halîl Ahmed es-Sehâranpûrî, Bezlû'l-mechûd (Hindistan: Merkezu'ş-Şeyh Ebi'l-Hasen en-Nedevî, 1427/2006), 4/122.

65 İbnu'l-İmâd Abdulhayy b. Ahmed, Şezerâtu'z-zeheb, thk. Mahmûd el-Arnaût (Dımaşk: Dâru İbn Kesir, 1406/1986), 3/418. 
M. BAYRAKTUTAR / The Hadith-Based Foundations of the Nafs Stages in Khalwatiyya Tradition (In the example of al-Atwar al-Sab'a Epistle Written by Yusuf Sunbul Sinan) | 27

\section{8. "Muhlisler Bile Büyük Bir Tehlikeyle Karşı Karşıyadır."}

Sünbül Efendi nefis mertebelerinin dördüncüsü olan nefs-i mutmainne (tavr-1 râbi') evresini izah ederken Hz. Peygamber'e nispet

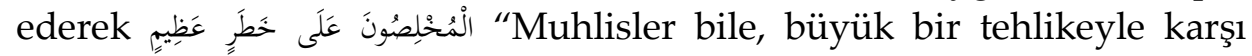
karşıyadır" şeklinde bir söze daha yer vermektedir. ${ }^{66}$

Sünbül Sinan'ın ifadesine göre nefs-i mutmainne, ihlas ehlinin makamıdır. Her ne kadar salike bazı ilahî sırlar gelip, kendisine hayret galebe çalsa da, bu makamda sâlik yine de nefs-i emmârenin birtakım tuzak ve hileleriyle karşı karşıyadır. ${ }^{67} \mathrm{Bu}$ sebeple sâlikin ihlasını korumasına dikkat çekmek amacıyla müellif, muhlislerin de büyük bir tehlikeyle karşı karşıya olduklarını temellendirmek amacıyla bu söze yer vermiştir.

Hadis kaynaklarında bu söz, hadis olarak tahric edilmemiştir. Başta Sağanî olmak üzere hadis âlimleri tarafından mevzû olarak nitelendirilmiştir. ${ }^{68}$ Bazı kaynaklarda ise sûfîlerin bazılarının sözü olarak nakledilmiştir. Meselâ Beyhakî, Zunnûn-1 Misrî́nin (ö. 245/859) sözü olarak şöyle nakletmiştir: "Âlimler hariç bütün insanlar ölüdür. Âmil olanlar hariç bütün âlimler uykudadır. Muhlis olanlar hariç âmil olanlar da aldanmıştır. Muhlis olanlar da büyük bir tehlike ile karşı karşıyadır. Nitekim Allah Teala "Ta ki o sadiklara sadakatlarından sual etsin" (elAhzâb, 33/8) buyurmuştur." 69

Tüsterî (ö. 283/896) ise bu sözü tefsirinde kendi sözü olarak ifade etmiş,70 Semerkandî (ö. 373/983) de Tüsterî́nin sözü olarak yer vermiştir. ${ }^{71}$ Gazzâlî de İhyâ'da Tüsterî'nin sözü olarak benzer anlamda ona şöyle nispet etmiştir: "Âlimler dışındaki insanların hepsi ölüdür.

66 Sinân, Etvâr-ı seb'a, 19 a.

67 Sinân, Etvâr-ı seb'a, 19 a.

68 Radiyyuddîn el-Hasen es-Sağânî, el-Mevzûât, thk. N. Abdurrahman Halef (Dımaşk: Dâru'l-Me'mûn, 1405), 38; Hût, Esne'l-metâlib, 309; Elbânî, Silsile, 1/174. Ayrica bk. Muhammed Tâhir el-Fettenî, Tezkiretu'l-mevzûât (b.y.: İdâretu't-Tibâa'ti'l-Munîre, ts.), 200; Aclûnî, Keşfu'l-hafâ, 2/312; Şevkânî, el-Fevâidu'l-mecmû'a, 257.

${ }^{69}$ Beyhakî, Şuabu'l-imân, thk. Abdulalî Abdulahmîd (Riyad: Mektebetu'r-Ruşd, 1423/2003), 9/181. Ayrıca bk. İbn Asâkir Ali b. el-Hasen Târihu Dımaşk, thk. Amr b. Garâme (Beyrut: Dâru'l-Fikr, 1415/1995), 17/429.

70 Sehl b. Abdullah et-Tusterî, Tefsîru't-Tusterî, thk. Muhammed Bâsil (Beyrut: Dâru'1kutubi'l-ilmiyye, 1423), 88.

71 Ebu'l-Leys Nasr es-Semerkandî, Tenbîhu'l-gâfilîn, thk. Yusuf Ali Bedeyvî (Dımaşk: Dâru İbn Kesîr, 1421/2000), 434. 
28 I M. BAYRAKTUTAR / Halvetiyye Geleneğindeki Nefis Mertebeleri Anlayışının Hadislerdeki Dayanakları (Yusuf Sünbül Sinân'ın Etvâr-ı Seb 'a Risâlesi Özelinde)

Amel edenleri müstesna, âlimler de sarhoştur. İhlâslılar dışında amel edenlerin de hepsi aldanmıştır. Muhlis de, amelinin neticesini bilene kadar korkudadır." 72 Gazzâlî bir başka eserinde Hz. Peygamber'e nispet ederken, ${ }^{73}$ Karâfî (ö. 684/1285) de yine Hz. Peygamber'e isnad etmiştir. ${ }^{74}$ Saîd Havva (ö. 1409/1989) ise Hasen-i Basrî́nin sözü olarak zikretmiştir. ${ }^{75}$ Sonuç olarak bu söz, ihlası korumanın önemi açısından mana bakımından problem arz etmemektedir. Ancak hadis âlimlerinin bu sözü mevzû olarak değerlendirdikleri de gözardı edilmemelidir.

\section{9. "Ben A'râf Ehlindenim."}

Müellif yine nefs-i mutmainne mertebesinin a'râf-1 suğrâ makamı olarak da isimlendirildiğini belirtmekte ve bu hususu Hz. Peygamber'e nispet ettiği انا من أهل الاعراف "Ben, a'râf ehlindenim" şeklindeki söz ile temellendirmektedir. ${ }^{76}$ Kaynaklarda bu şekilde herhangi bir söz veya rivayet tespit edilememiştir. Bu bakımdan bu sözün Hz. Peygamber'e hadis olarak nispeti isabetli değildir.

\subsection{0. "Beni Rüyasında Gören, Gerçekten Görmüştür."}

Sünbül Sinân yine nefs-i mutmainne mertebesine ilişkin olarak Hz.

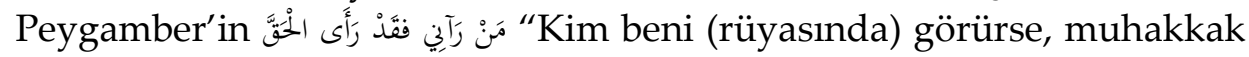
hakk1 (gerçekten beni) görmüştür" şeklindeki hadisine yer vermiştir.77 Hadis, Buhârî ve Müslim gibi temel hadis kaynaklarında rivayet edilmiş sahih bir hadistir. ${ }^{78}$

Sünbül Sinan müteakiben yine aynı konuyla ilgili olarak başta

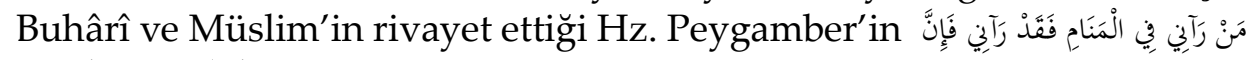
“Kim beni rüyada görürse, kesin beni görmüştür. Zira şeytan benim suretime giremez" 79 hadisini zikretmektedir. ${ }^{80}$

72 Gazzâlî, İhyâu ulûmi'd-dîn, 1/61.

73 Ebû Hâmid Muhammed el-Gazzâlî, Mizânu'l-amel, thk. Suleyman Dunyâ (Mısır: Dâru'l-Maârif, 1964), 269.

74 Şihâbuddîn Ahmed el-Karâfî, el-Furûk (b.y.: Âlemu'l-Kutub, ts.), 4/264, 289.

75 Saîd Havvâ, el-Esâs fi't-tefsîr (Kahire: Dâru's-Selâm, 1424), 6/2882, 8/4801.

76 Sinân, Etvâr-ı seb'a, 19 b.

77 Sinân, Etvâr-ı seb'a, 19 a.

78 Buhârî, "Ta'bir", 10; Muslim "Ru'yâ", 11; Abdullah b. Abdurrahman ed-Dârimî (ö. 255/869), Sunen, thk. Huseyn Selim ed-Dârânî (Riyâd: Dâru'l-Muğnî, 2000), "Ru'yâ", 4"; Ahmed b. Hanbel, el-Musned, 17/292.

79 Buhârî, "İlim", 38, "Edeb", 109, "Ru'yâ", 10; Muslim, "Ru’yâ", 10, 11; Tirmizî, "Ru'yâ", 4; Dârimî, "Ru'yâ", 4; Ahmed b. Hanbel, el-Musned, 15/188, 296, 16/44, 89, $115,21 / 339,17 / 291$. 
M. BAYRAKTUTAR / The Hadith-Based Foundations of the Nafs Stages in Khalwatiyya Tradition (In the example of al-Atwar al-Sab'a Epistle Written by Yusuf Sunbul Sinan) I 29

Sünbül Sinân'a göre, birinci hadiste ilme'l-yakîn, ikinci hadiste ayne'l-yakîn kastedilmiştir. Buradan hareketle müellif rüyada $\mathrm{Hz}$. Peygamber'i görme ile ilgili hadisleri, nefs-i mutmainne makamında Allah'ın zatının büyüklüğünün idrak edildiğini, bu makamın vahdet nuru mertebesi olduğunu, kesretin bu makamda vahdete dönüştüğünü, beşerî etkilerin ortadan kaybolduğunu, sâlikin istiğrak halinde olduğunu, kendi iradesi ile yapacağı bir tercihinin kalmadığını ve artık mahza tevhide ulaşıncaya kadar tüm vücudunun cezbe halinde olduğunu temellendirme bağlamında zikretmektedir. ${ }^{81}$

Sünbül Efendi'nin bu değerlendirmeleriyle hadisin zahiri anlamına işarî manalar yüklediği görülmektedir. Hadisin bu şekilde bir

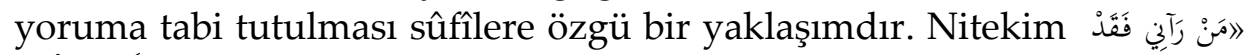

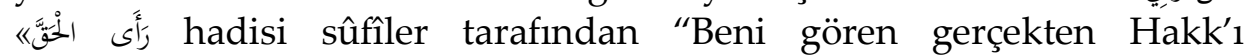
görmüştür" şeklinde de anlaşılmış ve vahdet-i vücud anlayışının delilleri arasında zikredilmiştir. Rivayetin vahdet-i vücuda delâleti açık değildir. Oysa hadis, Allah'ın değil, Hz. Peygamber'in rüyada görülmesiyle ilgilidir. $\mathrm{Bu}$ sebeple bağlantı kurmakta zorluk çekilmektedir. ${ }^{82}$ Zira şârihler hadisteki "Hakk" ifadesini Hakk'ı görmek değil, rüyâ-1 sahîha ve sâdıka olarak Hz. Peygamber'i görmek olarak açıklamışlardır. ${ }^{83}$ Sonuç olarak başta şârihler olmak üzere zahir ulemâsı hadisin zahirî anlamını, Sünbül Sinan gibi sûfîler ve bâtın ulemâsı disiplin ve öğretilerinin bir gereği olarak batınî ve işarî anlamını esas almıştır.

\subsection{1. "Mü'minin Kalbi Allah'1n Hazineleridir."}

Müellif, sülûk mertebelerinin beşincisi olan nefs-i râziyeyi (tavr-1 hâmis) izah ederken Hz. Peygamber'in: قلب المؤمن خزائن الله "Mü'minin kalbi Allah'ın hazineleridir" buyurduğunu zikretmektedir. ${ }^{84}$

80 Sinân, Etvâr-ı seb'a, 19 b.

81 Sinân, Etvâr-ı seb'a, 19 b. Ayrıca krş. Ayiş, "Sünbül Sinân ve Atvâr-ı Seb’a Risalesi", 130.

82 Ahmet Yıldırım, Tasavvufun Temel Öğretilerinin Hadislerdeki Dayanakları (Ankara: TDV Yayınları, 2013), 102.

83 İbn Hacer el-Askalânî, Fethu'l-Bârî şerhu Sahîhi'l-Buhârî (Beyrut: Dâru'l-Ma'rife, 1379), 12/389; Celâluddin Abdurrahman es-Suyûtî, ed-Dîbâc alâ Sahîh-i Muslim b. el-Haccâc, thk. Ebû İshak el-Huveynî (Suûdiyye: Dâru İbn Affân, 1416/1996), 5/287.

84 Sinân, Etvôrr-ı seb'a, 20 a. 
30 I M. BAYRAKTUTAR / Halvetiyye Geleneğindeki Nefis Mertebeleri Anlayışının Hadislerdeki Dayanakları (Yusuf Sünbül Sinân'ın Etvâr-ı Seb ‘a Risâlesi Özelinde)

Müellife göre bu mertebe tevhidde fark makamı olarak isimlendirilir ve O'nun Zât'ından başka her şeyin yok olduğu makamdır. Bu mertebede vücudun fenâya ulaşması gerçekleşir ve sâlik bu evrede tecelli şarabından içer. ${ }^{85}$ Nitekim o, "bu makam "Benimle görür, benimle konuşur ve benimle işitir" makamıdır" diyerek $\mathrm{Hz}$. Peygamber' den kudsî olarak nakledilen "Kulum bana nafile ibadetlerle de yaklaşmaya devam eder de nihayet ben onu severim. Onu sevdiğim zaman da, artık onun işiten kulağı, gören gözü, tutan eli ve yürüyen ayağı olurum..". ${ }^{86}$ hadisine atıfta bulunmaktadır. ${ }^{87}$ Müellif bu mertebede sâlikin kalbinde doğan tecellileri hadisle temellendirmek amaciyla "Mü'minin kalbi Allah'ın hazineleridir" sözüne yer vermektedir.

Kaynaklarda bu lafızla bir hadis tespit edilememiştir. Munâvî, Abdurrazzak'ın Katâde' den mürsel olarak naklettiği “İnsanların kalpleri Allah'ın hazineleridir ve anahtarları O'nun elindedir" şeklinde bir söze yer vermektedir. ${ }^{88}$ Ancak Abdurrazzak'ın bu şekilde bir rivayeti tespit edilememiştir.

Sûfî kaynaklarda kalplerin Allah'ın hazinesi olduğu ifadesi, hadis olarak değilde, bazı zâhid ve sûfîlerin sözü olarak yer aldığı görülmektedir. Örneğin Cüneyd-i Bağdadî şöyle demiştir: “Allah Teâlâ'nın göklerdeki hazineleri gaybler (guyûb), yerdeki hazineleri kalpler (kulûb)dir. O, allâmu'l-guyûb ve mukallibu'l-kulûbdür." 89 Cüneyd'in bu sözü Ebû Saîd el-Harrâz'a da nispet edilmiştir. Harrâz ayrıca Allah'ın mü'minin kalbini, hazinelerinin evi olarak yarattığını belirtmektedir. ${ }^{90}$ Hakîm et-Tirmizî ise mü'minlerin kalbinin Allah'1 bilmenin hazinesi olduğunu belirten ilk sûfîlerden biridir. ${ }^{91}$ Hakim et-

85 Sinân, Etvâr-ı seb'a, 20 a.

86 Buhârî, "Rikâk", 38.

87 Sinân, Etvâr-ı seb'a, 19 b.

88 Zeynuddîn Abdurraûf el-Munâvî, et-Teysîr bi-şerhi'l-Câmi'i's-să̆îr (Riyâd: Mektebetu'l-İmami'ş-Şâfi'î, 1408/1988), 2/382.

89 Fahruddîn Muhammed er-Râzî, Mefâtîhu'l-gayb (Beyrut: Dâru İhyai't-Turâsi'l-Arabî, 1420), 30/549.

90 Muhammed b. el-Huseyn es-Sulemî, Hakâiku't-tefsîr, thk. Seyyid Amrân (Beyrut: Dâru'l-kutubi'l-ilmiyye, 1421/2001), 1/344.

91 Muhammed b. Alî el-Hakîm et-Tirmizî, Nevâdiru'l-usûl, thk. Abdurrahman Umeyra (Beyrut: Dâru'l-Ciyl, ts.), 3/235; Hakîm et-Tirmizî, el-Emsâl mine'l-Kitab ve's-sunne, thk. es-Seyyid el-Cemîlî (Beyrut: Dâru İbn Zeydûn, ts.), 107. 
M. BAYRAKTUTAR / The Hadith-Based Foundations of the Nafs Stages in Khalwatiyya Tradition (In the example of al-Atwar al-Sab'a Epistle Written by Yusuf Sunbul Sinan) I 31

Tirmizî bir başka eserinde yine kalplerin Allah'ın hazineleri olduğunu ifade etmiştir. ${ }^{22}$

Sonuç olarak kalplerin Allah'ın hazineleri olduğu şeklindeki sözleri Hz. Peygamber'in hadisi olarak kabul etmek mümkün değildir. Bu rivâyet esasen bazı zâhid ve sûfîlerin sözlerinden ibarettir. Bu durum zâhid ve sûfîlerin bazı sözlerinin müteahhir dönemlerde $\mathrm{Hz}$. Peygamber'e nispet edilerek hadisleştirildiğinin bir örneğini teşkil etmektedir.

\subsection{2. "Kavmin Efendisi, Onlara Hizmet Edendir."}

Müellif, sülûk mertebelerinden altıncısı (tavr-1 sâdis) olan nefs-i

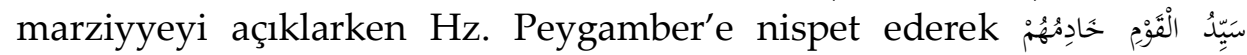
"Kavmin efendisi, onlara hizmet edendir" sözüne yer vermektedir.93 Zira ona göre bu makam enbiyâ, yani hizmet makamıdır ve onlar büyüklüğü hizmette görmüşlerdir. $\mathrm{O}$, bu mertebenin özelliğini ve bu husustaki görüşünü "Kavmin efendisi, onlara hizmet edendir" sözüyle temellendirmiş, kalbi ve ruhuyla bu hizmeti yerine getiremeyenlerin kurbet ve vuslata nail olamayacağını belirtmiştir. ${ }^{94}$

Hadisi Abdullah b. el-Mübârek (ö. 181/797) Hz. Peygamber'e isnad ederek "Kavmin efendisi, yolculukta onlara hizmet edendir" şeklinde rivayet etmiştir.95 Saîd b. Mansûr (ö. 227/842) Hz. Peygamber'in "Kavmin sevap bakımından en üstünü, onlara hizmet edendir" buyurduğu şeklinde bir haber nakletmiştir.96 Beyhakî de $\mathrm{Hz}$. Peygamber'e nispet ederek "Yolculukta kavmin efendisi onlara hizmet edendir. Hizmetle onları geride bırakan kimseyi, şehitlik dışında hiç kimse başka bir amelle onu geçemez" ifadesiyle rivayet etmiştir. ${ }^{97}$ Bazı hadis, tarih ve tasavvuf ağırlıklı eserlerde ise "Kavme hizmet eden, onların efendisidir" şeklinde kaydedilmiştir. ${ }^{98}$ Suyutî hadisin İbn Mâce

92 Hakîm et-Tirmizî, el-Emsâl, 107.

93 Sinân, Etvâr-ı seb'a, 21 a.

94 Sinân, Etvâr-ı seb'a, 21 a.

95 Abdullah b. el-Mubârek, el-Cihâd, thk. Nezîh Hammâd (Tunus: ed-Dâru't-Tunûsiyye, 1972), 159.

96 Saîd b. Mansûr, Sunen, thk. Habiburrahman el-A'zamî (Hindistan: ed-Dâru'sSelefiyye, 1403/1982), 2/191.

97 Beyhakî, Şuabu'l-imân, 10/582.

98 Sulemî, Âdâbu's-suhbe, thk. M. Fethî es-Seyyid (Tantâ: Dâru's-Sahâbe li't-Turâs, 1410/1990), 89; Ebû Nuaym, el-Erbaûn, 59; Hatîb Bağdâdî, Tarîhu Bă̆dâd, thk. Beşşâr Avvâd Ma'rûf (Beyrut: Dâru'l-Garbi'l-İslâmî, 1422/2002), 11/430; Abdulkerîm b. 
32 I M. BAYRAKTUTAR / Halvetiyye Geleneğindeki Nefis Mertebeleri Anlayışının Hadislerdeki Dayanakları (Yusuf Sünbül Sinân'ın Etvâr-ı Seb ‘a Risâlesi Özelinde)

tarafından rivayet edildiğini ifade etmiş olsa da ${ }^{99}$ İbn Mâce'nin (ö. 273/887) Sunen'inde böyle bir rivayet yer almamaktadır.

Muhaddisler "Kavmin efendisi, onlara hizmet edendir" rivayetini genel olarak zayıf olarak değerlendirmiş, bazıları ise tariklerinin çokluğu sebebiyle hasen ligayrihi olarak da değerlendirilebileceğini belirtmiştir.100 Müellifin hizmet makamı olarak değerlendirdiği nefs-i marziyye mertebesi için her ne kadar zayıf da olsa, uygun bir hadis seçtiğini söylemek mümkündür. Kezâ halka hizmeti ifade eden hadisi, İslam'a hizmet yönüyle zahirî anlamıla da değerlendirerek, esasen halka hizmetin Hakk'a hizmet olduğu anlayışına vurguda bulunduğu anlaşılmaktadır.

\subsection{3. "Fakirlik Neredeyse Küfür Olacaktı."}

Sünbül Sinân Efendi yine altıncı mertebe olan nefs-i marziyyeden bahsederken, bu evrede sâlikin kayıtların tamamından sıyrılması ve Hz.

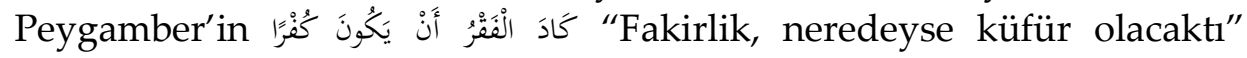
hadisine göre kişinin terakki etmesi gerektiğini, bunun da fakr mertebesinin ilki olduğunu ifade etmektedir. ${ }^{101}$ Dolayısıyla müellif tasavvuftaki "fakr" anlayışını Hz. Peygamber'e nispet ettiği bu sözle temellendirmeye çalışmıştır.

Hadis temel hadis kaynaklarında yer almayıp, muhtelif bazı eserlerde Hz. Peygamber'e nispet edilerek rivayet edilmiştir. ${ }^{102}$ Taberânî

Hevâzin el-Kuşeyrî, Letâifu'l-işârât, thk. İbrahim el-Besyûnî (Mısır: el-Hey'etu'lMisriyye, ts.), 2/281; Abdulkerîm b. Hevâzin el-Kuşeyrî, er-Risâletu'l-Kuşeyriyye, thk. Abdulhalim Mahmûd - Mahmud b. eş-Şerîf (Kahire: Dâru'l-Maârif, ts.), 2/373; Ummu'l-Fazl Bîbî bnt. Abdussamed, Cüz'ü Bîb̂̂, thk. Abdurrahman b. Abdulcebbâr (Kuveyt: Dâru'l-hulefa, 1986), 69; Muhammed b. Ebî Sehl es-Serahsî, Şerhu's-Siyeri'lkebîr (b.y.: eş-Şeriketu'ş-Şarkiyye, 1971), 29-30; Deylemî, el-Firdevs, 2/324.

99 Suyûtî, ed-Dureru'l-muntesira, 131.

100 Sehâvî, el-Makâsıdu'l-hasene, 395-396; Sehâvî, el-Ecvibetu'l-murdiyye, thk. Muhammed İshâk (b.y.: Dâru'r-Râye, 1418) 1/103-104; Aclûnî, Keşfu'l-hafâ, 1/462-463; Hût, Esne'lmetâlib, 761; Elbânî, Silsile, 4/9.

101 Sinân, Etvôr-ı seb'a, 21 b.

102 Abdullah b. Muhammed İbn Ebi'd-Dunyâ, Islâhu'l-mâl, thk. M. Abdulkadir Atâ (Beyrût: Müessesetu'l-kutubi's-sikâfiyye, 1414/1981), 121; Muhammed b. Amr elUkaylî, ed-Duafâu'l-kebîr, thk. A. Emîn Kal'acî (Beyrut Dâru'l-kutubi'l-ilmiyye, 1404/1984), 4/206; Ebû Ahmed b. Adî el-Curcânî el-Kâmil fî duafâi'r-ricâl, thk. Âdil A. Abdulmevcûd (Beyrût: Dâru'l-kutubi'l-ilmiyye, 1418/1997), 9/94; Ebu'ş-Şeyh, etTevbîh ve't-tenbîh, thk. M. es-Seyyid İbrâhim (Kahire: Mektebetu'l-Furkan, ts.), 41, 43; Muhammed b. Ebî İshâk el-Kelâbâzî, Bahru'l-fevâid, thk. Muhammed Hasen - Ahmed 
M. BAYRAKTUTAR / The Hadith-Based Foundations of the Nafs Stages in Khalwatiyya Tradition (In the example of al-Atwar al-Sab'a Epistle Written by Yusuf Sunbul Sinan) I 33

lafziyla "Hâcet ve ihtiyaç neredeyse küfür olacaktı" şeklinde tahric etmiştir. ${ }^{103}$ Muhaddisler "Fakirlik, neredeyse küfür olacaktı" hadisini zayıf olarak nitelendirmiştir.104 İsnadı zayıf olan bu sözün zahiri maddî fakirliği çağrıştırırken, müellif tarafından işârî olarak tasavvufî anlamda da kullanılmıştır.

\subsection{4. "Fakirlik Övüncümdür."}

Müellif sülûkun yedinci mertebesi olan nefs-i kâmile (tavr-1 sâbi') bağlamında Hz. Peygamber'in الْنَرُر فَخْرِي akakirlik övüncümdür” hadisine yer vermektedir. ${ }^{105}$ Sünbül Sinân'a göre bu makam insanın fakrının son bulduğu ve vuslata erdiği makamdır. Bu mertebeden maksat, fakr sırlarına muttali olmaktır. Ancak bu durumda fakr tamam olur. Bu sebeple bu tür fakrdan fahr-i âlem Hz. Peygamber iftihar etmiş ve "Fakirlik övüncümdür" buyurmuştur. ${ }^{106}$

Temel hadis kaynaklarında "Fakirlik övüncümdür" şeklinde bir hadis kaydedilmemiştir. Bu söz, mevzûât kitaplarında ve halk arasında

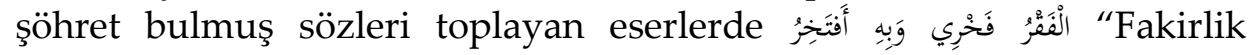
övüncümdür ve ben onunla övünürüm" ifadesiyle yer almakta olup başta İbn Hacer olmak üzere muhaddisler ve âlimler tarafından bâtıl ve mevzû olarak değerlendirilmiştir.107 Her ne kadar Bursevî (ö. 1137/1728)

Ferîd (Beyrût: Dâru'l-kutubi'l-ilmiyye, 1420/1999), 56; Ebû Nuaym Ahmed b. Abdullah, Hilyetu'l-evliyâ (Misr: Dâru's-Saâde, 1394/1974), 3/53, 109, 8/253; Kudâî, Musnedu'ş-Şihâb, 1/342; Beyhakî, Şuabu'l-imân, 9/12.

103 Taberânî, el-Mu'cemu'l-evsat, 4/225.

104 Ebu'l-Ferec İbnu'l-Cevzî, el-ílelu'l-mutenâhiye, thk. İrşâdulhak el-Eserî (Faysalâbâd: İdâretu'l-ulûmi'l-eseriyye, 1401/1981), 2/320; Zehebî, Mîzânu'l-itidâl, 4/416; İbn Hacer, el-Metâlibu'l-âliye, 12/34; Zeynuddîn Abdurrahim el-Irâkî, Tahrîcu ehâdîsi İhyâi ulûmi'd-dîn (Riyâd: Dâru'l-Âsıme, 1408/1987), 4/1387; Sehâvî, el-Makâsidu'l-hasene, 497; Sehâvî, el-Ecvibetu'l-murdiyye, 2/606; Zeynuddîn Abdurraûf el-Munâvî, Feyzu'lkadîr (Misr: el-Mektebetu't-Ticâriyyeti'l-Kubrâ, 1356), 4/542; Aclûnî, Keşfu'l-hafâ, 2/107-108; Elbânî, Silsile, 9/77.

105 Sinân, Etvâr-ı seb'a, 22 a. “

106 Sinân, Etvâr-ı seb’a, 22 a. Ayrıca bk. Ayiş, "Sünbül Sinân ve Atvâr-1 Seb’a Risalesi”, 133-134.

107 Sağânî, el-Mevzĥât, 52; Takıyyuddîn Ahmed b. Teymiyye, el-Fetâva'l-kubrâ, thk. M. Abdulkadir Atâ (Beyrut: Dâru'l-kutubi'l-ilmiyye, 1408/1987), 5/89; Takıyyuddîn Ahmed b. Teymiyye, Mecmû'ul-fetâvâ, thk. Abdurrahman b. Muhammed (Medîne: Mecmau'l-Melik Fahd, 1416/1996), 11/117, 18/123; İbn Hacer, et-Telhîsu'l-habîr, thk. Hasen b. Abbâs (Misr: Muessesetu Kurtuba, 1416/1996), 3/234-235; Sehâvî, el- 
34 I M. BAYRAKTUTAR / Halvetiyye Geleneğindeki Nefis Mertebeleri Anlayışının Hadislerdeki Dayanakları (Yusuf Sünbül Sinân'ın Etvâr-ı Seb ‘a Risâlesi Özelinde)

manasının doğru olduğunu ifade etmiş olsa da, ${ }^{108}$ hadis âlimlerinin mevzû ve batıl olarak değerlendirmeleri bu sözün Hz. Peygamber'e nispetini güçleştirmekte ve asılsız olduğunda bir şüphe birakmamaktadır. ${ }^{109}$

Kişinin maddî yönden insanlara muhtaç olması anlamındaki fakirlik dinen makbul olmayan bir durumdur. Nitekim $\mathrm{Hz}$. Peygamber'in "Allahım, küfürden ve fakirlikten sana sığırım" şeklinde dua ettiğine dair temel hadis kaynaklarında isnadı sahih pek çok hadis nakledilmiştir. ${ }^{110}$ Dolayısıyla eğer fakirlik övünelecek bir durum olsaydı, kanaatimizce Hz. Peygamber'in fakirlikten Allah'a sığınması beklenemezdi.

Tasavvufta fakirlik, dünyevi anlamından farklı bir mahiyet arzetmektedir. Tasavvufi anlayışa göre fakirin, mal-mülk sahibi olmasında bir beis yoktur, ancak buna rağmen sâlik kendini fakir hissedebilmelidir. Zira o her şeyde Allah'a muhtaç, mal, mülk ve kendi varlığ1 dahil herşeyin Allah'a ait olduğu bilinciyle hareket etmelidir. ${ }^{111}$ $\mathrm{Bu}$ sebeple tasavvufta fakr; kulun kendini daima Allah'a muhtaç hissetmesi, kendi varlığının gerçek sahibinin de Mevlâsı olduğu bilincine ulaşması olarak açıklanmış; tevbe, vera', zühd, fakr, sabır, tevekkül, rızâ şeklinde sıralanan sûfî makamların dördüncüsü olarak fakr kabul edilmiştir. ${ }^{112} \mathrm{Bu}$ bağlamda tasavvufta küfre yakın fakirlik ile kalbteki kinin, ilim, hikmet, ahlak, sabır, rıza, teslimiyet ve tevekkülü yok ederek kalbin bu sifatlardan yoksun hale gelmesi, iftihar olan fakirlik ile de kişinin dünyadan arınarak Hakka yakın olmasının kastedildiği ifade edilmiştir. ${ }^{113}$

Sünbül Sinân "Fakirlik övüncümdür" sözünün, hadis ilminin kriterlerine göre hadis olarak aslı olmadığı halde, Hz. Peygamber'e

Makâsıdu'l-hasene, 480; Kârî, el-Masnû̀', thk. Abdulfettah Ebû Gudde (Mektebu'lMatbûâti'l-İslâmiyye, ts.), 128; Aclûnî, Keşfu'l-hafâ, 2/87.

108 Bursevî, R̂̂hu'l-beyân, 7/334.

109 Muhittin Uysal, Tasavvuf Kültüründe Hadis (İstanbul: Ensar Yayınları, 2002), 568-569.

110 Ebû Dâvûd, "Edeb", 99-101; Nesâî, "Sehv", 89, "İstiâze", 15, 28; Ahmed b. Hanbel, elMusned, 34/17, 52, 75, 97.

111 Uysal, Tasavouf Kültüründe Hadis, 568.

112 Süleyman Uludağ, "Fakr", Türkiye Diyanet Vakfi İslam Ansiklopedisi (İstanbul: TDV Yayınları, 1995), 12/133.

113 Seyyid Cafer es-Seccâdî, "Fakr", Tasavouf ve Irfan Terimleri Sözlüğ̈̈̈, çev. Hakkı Uygur (İstanbul: Ensar Neşriyat, 2007), 148. 
M. BAYRAKTUTAR / The Hadith-Based Foundations of the Nafs Stages in Khalwatiyya Tradition (In the example of al-Atwar al-Sab'a Epistle Written by Yusuf Sunbul Sinan) I 35 nispet etmekte bir beis görmemiş, fakr makaminı temellendirmede delil olarak kullanmış, sonuçta yine manayı esas alarak genel olarak sûfîlerin hadis kullanımlarındaki tutumlarına benzer bir yaklaşım sergilemiştir.

\subsection{5. "Kim Allah'1 Tanırsa, Dili Tutulur."}

Sünbül Sinân, yine yedinci mertebe olan nefs-i kâmile makaminı izah ederken Hz. Peygamber'in من عرف الله كل لسانه "Kim Allah'ı tantrsa, dili tutulur" buyurduğunu belirtmektedir. ${ }^{114}$

Nevevî (ö. 676/1277) bu sözün hadis olarak sabit/aslının olmadığını ifade etmiş, ${ }^{115}$ Suyûtî ve Ali el-Kârî ise Nevevî'nin değerlendirilmesine yer vermiştir. ${ }^{116}$ Dolayısıyla hadis olduğuna dair bir kayıt bulunmayan bu sözün, aslında sûfîlere ait bir söz olduğu ifade edilmiştir. ${ }^{117}$

Ukaylî (ö. 322/934) ise "Kim Rabbine karşı muttakî olursa, dili sukût eder" şeklinde bir rivayete yer vermiş, ancak ravisi Abddurrahman $b$. Harîz'in meçhul olduğunu ve rivayetine mutabaat edilmediğini ifade etmiştir. ${ }^{118}$ İbn Asâkîr (ö. 571/1176) Fudayl b. İyâd'ın sözü olarak "Kim Allah'tan korkarsa, dili susar" ifadesiyle nakletmiştir. ${ }^{119}$ Cüveynî (ö. 478/1085) de Glyâsi'l-ümem adlı eserinde bu sözü kullanmaktadır. ${ }^{120}$ Bazı kaynaklarda hadisin hem Hz. Peygamber'e nispet edildiği hem de nispet edilmediği görülmektedir. Meselâ Râzî (ö. 606/1210) bir yerde senedsiz olarak Hz. Peygamber'e nisbet ederken, ${ }^{121}$ bir başka yerde bu sözü Hz. Peygamber'e nispet etmeksizin tefsirinde yer vermektedir. Nitekim o, Allah'ın zikrinin nuruyla kalbin dolmasıyla

114 Sinân, Etvâr-ı seb'a, 22 a.

115 Yahyâ b. Şeref en-Nevevî, Fetâvâyı'l-Imami'n-Nevevî, thk. Muhammed el-Haccâr (Beyrût: Dâru'l-beşâir, 1417/1996), 248.

116 Kârî, el-Masnû, 189; Fettenî, Tezkiretu'l-mevzĥât, 11; Aclûnî, Keşfu'l-hafâ, 2/262. Ayrica bu sözü Abdulkadir Geylânî'nin el-Fethu'r-Rabbânî adlı eserinde Hz. Peygamber'e isnad ettiği, ancak eserin muhakkikinin, bu sözün mevzû olduğu yönünde not düştüğü belirtilmiştir. Bk. Uysal, Tasavvuf Kültüründe Hadis, 482-483.

117 Uysal, Tasavvuf Kültüründe Hadis, 483.

118 Ukaylî, ed-Duafâu'l-kebîr, 2/327; Zehebî de söz konusu ravinin meçhul olduğunu kaydetmiştir. Zehebî, Mîzânu'l-i'tidâl, 2/556. Ayrıca bk. İbn Hacer, Lisânu'l-Mîzân, 5/94.

119 İbn Asâkir, Târîhu Medîneti Dımaşk, 48/429.

120 İmâmu'l-Haremeyn Ruknuddîn el-Cuveynî, Gıyâsu'l-umem fi't-teyyâsi'z-zulem, thk. Abdulazîm ed-Dîb (b.y.: el-Mektebâtu'l-Kubrâ, 1401), 5.

121 Râzî, Mefâtîhu'l-gayb, 15/443. 
36 I M. BAYRAKTUTAR / Halvetiyye Geleneğindeki Nefis Mertebeleri Anlayışının Hadislerdeki Dayanakları (Yusuf Sünbül Sinân'ın Etvâr-ı Seb ‘a Risâlesi Özelinde)

dilin sustuğunu ve zikrin kalpte baki kaldığını ifade etmekte, bu yüzden de مَنْ عَرَفَ النَّ كَلَّ لِسَانُهُ "Kim Allah'1 bilirse dili tutulur" denildiğini belirtmektedir. ${ }^{122}$ Bursevî de Hz. Peygamber'e nispet etmeksizin bu söze tefsirinde yer vermektedir. ${ }^{123}$

Müellif bu sözün de anlamını esas alarak etvar-1 seb'anın en üst mertebesine vâsıl olan sâlikin yaşadı̆̆ 1 halleri temellendirme bağlamında delil olarak kullanmış, Hz. Peygamber'den sabit olup olmadığına bakmamıştır.

\subsection{6. "Ben Gizli Bir Hazineydim."}

Müellif nefs-i kâmile makamında mü'minin kalbinin, ism-i âzam'ın Zât'ının mazharı olduğunu, bu mertebenin Ahmediyye tavrı olarak isimlendirildiğini, Hz. Ahmed'in ehadiyet sırlarını kendisinde topladığını ve Ahmed'deki mim kaldırılınca, geriye kalan Ehad isminin Resûl-i Ekrem'in söylediği ism-i âzama delalet ettiğini, كنت كنزا sirrının zuhuru için de ruh-1 âzamın nurunu indirdiğini ifade etmektedir. ${ }^{124}$ Böylece müellif "Ben gizli bir hazineydim" sözünü bu bağlamda delil olarak kullanmakta, ancak Hz. Peygamber'e nispet etmemektedir.

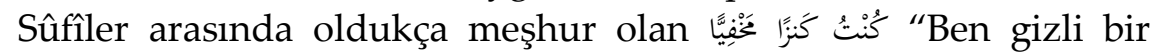
hazineydim" şeklinde bir söz herhangi bir hadis kaynağında kaydedilmemiştir. Tasavvufta çok önemli bir yeri hâiz olmasına karşın, başta İbn Teymiyye (ö. 728/1328), Zerkeşî (ö. 794/1392), İbn Hacer ve Suyûtî tarafından, sahih veya zayıf herhangi bir senedi ve aslı bulunmayan bir söz olarak olarak değerlendirilmiştir. ${ }^{125}$ Bazı âlimler ise manasının doğruluğuna dikkat çekmiş, ${ }^{126}$ Bursevî de İbnu'l-Arabî'nin (ö. 638/1240) bu hadisin keşfen sahîh olduğunu, ancak naklen sabit olmadığını ifade ettiğini, kendisinin de aynı görüşte olduğunu belirtmiş ve bu sözü şerheden Kenz-i Mahfî isimli bir eser telif etmiştir. ${ }^{127}$ Ancak

122 Râzî, Mefâtîhu'l-gayb, 8/216.

123 Bursevî, Rûhu'l-beyân, 2/31, 4/154, 5/332.

124 Sinân, Etvâr-ı seb'a, 22 b. Krş. Yıldız, "Etvâr-1 Seb'a”, 186-187.

125 Sehâvî, el-Makâsıdu'l-hasene, 521; Suyûtî, ed-Dureru'l-muntesira, thk. M. Lutfi esSabbâğ (Riyâd: Câmiatu'l-Melik Suûd, ts.), 163; Kârî, el-Esrâru'l-merfûa, 273; Kârî, elMasnû, 141; Aclûnî, Keşfu'l-hafâ, 2/132; Şevkânî, el-Fevâidu'l-mecmûa, 103.

126 Kârî, el-Esrâru'l-merfûa, 273; a.mlf., el-Masnû, 141.

127 İsmail Hakkı Bursevî, Kenz-i Mahfî (İstanbul: y.y., 1980), 10-11. Kenz hadisi hakkındaki değerlendirmeler için ayrıca bk. Fikret Karapınar, "Rivayetlerde İşârî Yorum", Hadis Tetkikleri Dergisi, 5/2 (2007), 100; Yıldırım, Tasavvufun Temel Öğretilerinin Hadislerdeki Dayanakları, 109-110. 

(In the example of al-Atwar al-Sab'a Epistle Written by Yusuf Sunbul Sinan) I 37 hadis ilminde rüyâ ve keşif yoluyla alınan rivayetler hadis olarak dikkate alınmamıştır. ${ }^{128}$ Bu sebeple hadis ilmi kriterlerine göre "Ben gizli bir hazineydim.." sözünü Hz. Peygamber'in bir hadisi olarak kabul etmek mümkün gözükmemektedir.

\section{Sünbül Sinân'in Hadise Yaklaşımının Değerlendirilmesi}

\subsection{Hadis Rivâyeti}

Sünbül Sinân'ın risâlede sûfî kimliğiyle hadisleri kullanma ve hadis anlayışı konusunda sergilediği tutum, genel olarak sûfîlerin hadise yaklaşımlarıyla örtüşmektedir.

Hadislerin sıhhat derecesini tespit, hadis ilminde ağırlık olarak sened tenkidine sonra metin tenkidine dayanmaktadır. Ancak sûfîler eserlerinde kullandikları rivayetlerin sihhatinden ziyade, kendi öğretileri açısından ifade ettiği anlama ağırlık vermişlerdir. Nitekim aynı yaklaşım Sünbül Sinân için de geçerlidir. Onlar hadise öğüt almak ve gereğiyle amel etmek için yönelmişler, hadislerin sihhat ve sübûtunu tespitte hadis ilminin kriterlerini yeterince dikkate almamışlardır. ${ }^{129} \mathrm{Bu}$ da onların eserlerinde zayıf birtakım rivayetlere yer vermelerinin temel sebeplerinden birini teşkil etmiştir. ${ }^{130} \mathrm{Bu}$ durum zayıf hadislerle sınırlı kalmamış, anlamının kendi öğretileri açısından doğru buldukları, aslı olmayan ve mevzû sayılan söz ve rivayetlere yer vermekten çekinmemişler ve oldukça mütesahil davranmışlardır. Nitekim bu eğilim Sünbül Sinân'da da görülen bir tavırdır.

\subsection{Hz. Peygamber'e Hadis İsnadı}

Sünbül Efendi risâlesinde bazı sûfîlerin sözleri için hadis ifadesini kullanarak, onları Hz. Peygamber'e nispet etmektedir. Onun bu yaklaşımın yine genel olarak sûfîlerin eğilimiyle örtüştüğü görülmektedir. Nitekim mevzuât türü eserlerde Hasan-1 Basrî, Malik b. Dinar, İbrahim b. Edhem, Zunnûn el-Misrî, Ebû Suleyman ed-Dârânî, Fudayl b. İyâd gibi zâhid ve sûfîlere ait olduğu ifade edilen sözlerin çoğunluğunun, uydurmacılar tarafından birer sened ilavesiyle hadis haline getirdikleri görülmektedir. Örneğin "küntü kenzen..." sözü gibi hadis olmayan, hiçbir sahih ve zayıf senedi bulunmayan, ancak bazı

128 Yıldırım, Tasavvufun Temel Öğretilerinin Hadislerdeki Dayanakları, 109-110.

129 Aydınl, Tasavouf ve Hadis, 160.

130 Ahmed Cahid Haksever, Tasavoufu Anlama Klavuzu (Ankara: Otto Yayınları, 2017), 23. 
38 I M. BAYRAKTUTAR / Halvetiyye Geleneğindeki Nefis Mertebeleri Anlayışının Hadislerdeki Dayanakları (Yusuf Sünbül Sinân'ın Etvâr-ı Seb ‘a Risâlesi Özelinde)

sûfîlerin sözleri arasında görülen ${ }^{131}$ bir cümle daha sonra hadis olarak ifade edilebilmektedir. Bu ise önceleri her türlü söz ve haber anlaminda kullanılan "hadis" ifadesinin, bir kısım kimselerin sözünü "fulanın hadisi" şeklinde nakledilmesinden kaynaklanabilmektedir. Sonraları "fulan" ifadesi kaldırılarak "hadis (söz)" olarak nakledilmeye başlanmış, akabinde de bu "hadis (söz) "Peygamber hadisi" olarak anlaşılmasına zemin hazırlamıştır. Bunda ise sözün kendisine nispet edildiği zâhid ve sûfînin herhangi bir dahli bulunmamaktadir. ${ }^{132}$ Oysa bu durumda yapılması gereken hadis diye ifade edilen her sözü hemen $\mathrm{Hz}$. Peygamber'e nispet etmemek, bilhassa hadis kaynaklarında Hz. Peygamber'e isnad edilen böyle bir hadisin bulunup bulunmadığını teyit etmektir. Aksi halde Hz. Peygamber'e ait olmayan bir sözü ona isnad etme gibi durum hasıl olur ki, bunun da bir tür hadis vaz'1 anlamına geldiği göz ardı edilememelidir. Zira hadis vaz'ının her türlüsü haram olup, bunun ahkâm ya da tergîb ve terhîb konularında olması arasında bir fark yoktur. Mevzû olan bir haberin sabit olduğuna inanarak rivayet edilmesi, zikredilmesi, nakledilmesi ve muhtevasiyla amel edilmesi de haramdır. Ancak dikkat çekmek için kaynaklarda yer verilmesinde ise bir beis bulunmamaktadır. ${ }^{133}$

\subsection{Hadislerin İşârî Yorumu}

Kur'ân'ın ve hadislerin zahirî yorumunun ötesine geçerek, işârî bir tavır sergilemek sûfîlere özgü bir yaklaşımdır. Onların ahkâma dair âyet ve hadisleri dahi, ahlâkî ve manevî yönden yorumlamaya çalışmaları, işârî yorumu ne kadar önemsediklerinin bir göstergesidir. Ancak işarî yorumun dil ve anlatım, batınî yoruma düşme tehlikesi, yorumda başka konulara kayma, zayıf ve mevzû haber kullanımı gibi birtakım mahzurları da vardır. Dolayısıyla her türlü işârî yorum makbul olmayıp, işarî yorumun makbul olmasının; başta verilen manaların, Kur'an ve Sünnet'e uygun olması, diğer âyet ve hadislerle desteklenmesi, lafzın/şeriatın zahirine ve akla ters düşmemesi, tek manada ısrar edilmemesi, hadisin te'vili ümmetin icma'ının dışına çıkmaması, metni zorlayan, haddi aşan, saptırıcı bir nitelik arzeden yorumlar olmaması

\footnotetext{
131 Aydinl, Tasavouf ve Hadis, 188-189.

132 Aydınl, Tasavouf ve Hadis, 188-189; Bu hususta ayrica bk. Celâluddin Abdurrahman es-Suyûtî, Tedrîbu'r-râvî, thk. Ebu Kuteybe el-Fâdyâbî (Riyad: Mektebetu'l-Kevser, 1415/1995), 1/338-340.

133 Aydinl, Tasavouf ve Hadis, 166.
} 
M. BAYRAKTUTAR / The Hadith-Based Foundations of the Nafs Stages in Khalwatiyya Tradition (In the example of al-Atwar al-Sab'a Epistle Written by Yusuf Sunbul Sinan) I 39 gibi birtakım kuralları bulunmaktadır. ${ }^{134}$ Sûfîler genel olarak işârî yorumlarında zâhir-bâtın dengesini korumuşlar, bâtın ilminde sapmaya yol açmaması amacıyla 'zâhire aykırı düşen her bâtın bâtıldır' ilkesini koymuşlardır. ${ }^{135}$ Sünbül Sinân da risâlesinde kullandığı bazı hadisler ve sözler üzerinde işârî yorumlarda bulunmuştur. Ancak o, yaptığ1 işarî yorumlarda, işarî yorumda aranan kuralları dikkate almış, zâhir-bâtın dengesini gözetmiş, genel olarak nassların zahirî anlamına aykırı dikkat çekici yorumlarda bulunmamıştır.

\subsection{Tasavvuf Sonrası Dönem Hadis Kullanımı}

Tasavvufun öğretilerini Kur'an ve Sünnet ile temellendirmek, bizzat bazı sûfîler tarafından da benimsenmiş ve önemi vurgulanmış temel bir ilkedir. Nitekim tasavvuf dönemi zâhid ve sûfî âlimlerinin, her düşünce ve öğretilerinin Kur'an ve Sünnet temelli olmasına özellikle vurguda bulundukları görülmektedir. Bu hususta Cüneyd elBağdâdî'nin (ö. 297/909) “Bu ilmimiz Kitab ve Sünnetle kayıtlanmıştır."136 Ebû Süleyman Dârânî'nin (ö. 215/830) ise: "Pek çok defa hakikat kalbime kırk gün gelir de Kitab ve Sünnetten iki delil olmadan onun kalbime girmesine izin vermem"137 ve Hâris elMuhâsibî'nin (ö. 243/857) "Kalbî amellerden kalbine bir hâtır gelen kimse hemen Kitab ve Sünneti bunlara delil kılsın"138 şeklindeki sözleri açıkça bu yaklaşımlarını ortaya koymaktadır. Bu da onların aslı olmayan ve uydurma olması muhtemel rivayetlere pek itibar etmediklerini göstermektedir. Ancak özellikle hicrî V. asırdan sonra gelen sûfîyye arasında uydurma haberler daha çok revaç bulmaya başlamıştır. ${ }^{139}$

134 Karapınar "Rivayetlerde İşârî Yorum", 93-102. Bu hususta geniş bilgi için ayrıca bk. Ahmet Yıldırım, "Hadisleri Anlamada İşârî Yorum" Süleyman Demirel Üniversitesi İlahiyat Fakültesi Dergisi 13 (2004), 21-25.

135 İbrahim Işıtan, “Dergâhlarda Zâhir-Bâtın Bilgi Dengesinin Sûfî Şahsiyet Gelişimine Katkısı ve Şeyh Şâbân-ı Velî Örneği”, III. Uluslararası Şeyh Şa'bân-ı Velî Sempozyumu, ed. Ali Rafet Özkan (Kastamonu: Kastamonu Üniversitesi Yayınları, 2016), 369.

136 Ebû Nuaym, Hilyetu'l-evliyâ, 10/255. Değerlendirmeler için ayrıca bk. Yıldırım, “Tasavvufun Kaynağı Olarak Hadis", Hadis ve Siyer Araştırmaları Dergisi 4/2 (2018), 60.

137 Ebû Nasr es-Serrâc et-Tûsî, el-Luma', thk. Abdulhalîm Mahmûd - Abdulbâkî Surûr (Misr: Dâru'1-Kutubi'l-Hadîse, 1380/1960), 146.

138 Hâris b. Esed el-Muhâsibî, er-Riâye li hukûkillâh, thk. Abdulkadîr Ahmed Atâ (Beyrut: Dâru'l-kutubi'l-ilmiyye, ts.), 94.

139 Karapınar, “Rivayetlerde İşârî Yorum”, 101. 
40 I M. BAYRAKTUTAR / Halvetiyye Geleneğindeki Nefis Mertebeleri Anlayışının Hadislerdeki Dayanakları (Yusuf Sünbül Sinân'ın Etvâr-ı Seb ‘a Risâlesi Özelinde)

Sonuçta tasavvuf sonrası dönemde ilk devirlerde pek bilinmeyen sözler ve aslı olmayan rivayetler sûfîlerin eserlerine yansımaya başlamış ve kabul görmüştür. Bu durum Sünbül Sinân için de geçerlidir. O da tasavvuf döneminde ve ilk dönem kaynaklarında yer almayan birtakım söz ve rivayetleri hadis diye risâlesine almakta ve görüşlerini temellendirmede bir beis görmemiştir. Burada ilk dönem sûfîleri ile sonraki dönem sûfîlerin hadis kullanımları arasında farklılaşmanın ortaya çıktığ1 görülmektedir. Sonraki dönem sufîlerinde hadislerin kendinlerine özgü olarak rüya, keşf ve ilham yoluyla tespiti anlayışının ortaya çıktığı, ayrıca hadisin rivayet yönünden sübutu ve sıhhatinden ziyade mana bakımından kendi öğretileri açısından doğruluğunu ölçü alan bir anlayış ve yaklaşımın yerleşmeye başladığı görülmektedir. $\mathrm{Bu}$ da onları manası doğru kabul edilen ancak aslı olmayan, zayıf ve mevzû bir takım rivayetleri kullanmalarına yol açmıştır. Bu eğilim, Sünbül Sinan'da da görülmekte olup, risalesinde bu tür söz ve rivayetlere yer vermesinin önemli sebeplerinden birini teşkil etmektedir.

\section{Sonuç}

Osmanlı döneminin meşhur Halvetî şeyhlerinden Sünbül Sinân, Halvetiyye geleneğinde Etvâr-1 Seb'a risâlesi kaleme alan müelliflerden biridir. $\mathrm{O}$, diğer etvâr müelliflerine nazaran risâlesinde nefis mertebelerini temellendirmede âyet ve hadislere daha fazla yer vermiştir. Çalışmada müellifin risâlede hadis olarak Hz. Peygamber'e nispet ettiğini rivayetler ve sözler tespit edilerek hadis ilminin kriterlerine göre değerlendirilmiştir.

Sünbül Sinân risalesinde sülûk mertebelerini temellendirmek amaciyla hadis olarak ifade ettiği ve atıfta bulunduğu 16 rivayeti veya sözü, birer delil ve dayanak olarak sunmuştur. Risâledeki hadis, söz ve rivayetlerin tespit, tahric ve tenkidleri neticesinde; bunlar arasında isnad açısından 1 sahih, 1 hasen ligayrihi, 3 zayıf hadis bulunmakta olup, geriye kalan 11 rivayet veya söz ise; hadis olarak aslı olmayan, bir kısmı mevzû olarak değerlendirilen, bazıları da kaynaklarda yer almayan söz ve riayetlerden oluşmaktadır. Ayrıca risâledeki söz konusu rivayetlerin kahir ekseriyetinin ilk dönem hadis ve tasavvuf kaynaklarında bulunmadığı, daha çok sonraki dönemlerde tasnif ve telif edilen kaynaklarda yer aldığı, hatta bazılarının kaynaklarda hiç yer almadığı görülmektedir. Dolayısıyla ilk dönemlerde bazı zahid, sûfî ve hikmet 

(In the example of al-Atwar al-Sab'a Epistle Written by Yusuf Sunbul Sinan) | 41 ehli kimselerin, ya da farklı kültür ve şahsiyetlere ait anlamı doğru kabul edilen sözlerin hadisleştirilerek sonraki dönem kaynaklarına yansıdığını ve tasavvufa geçtiğini söylemek mümkündür. Bu bakımdan tasavvufta etkili olan ve hadis olarak kullanılan rivayetlerin kaynağı ve tasavvufa intikali hakkında daha derinlikli araştırmalara ihtiyaç duyulmaktadır. Sünbül Sinân'ın risâledeki hadis kullanımına ve hadis anlayışına bakıldığında, genel olarak tasavvuf erbabının hadise yaklaşımına benzer bir tutum sergilediği görülmektedir. Müellif, hadisleri delil olarak sunmada hadisin sihhat ve sübûtundan ziyade, kendi öğretilerini temellendirme ve izah etme açısından manasının uygunluk arzedip arzetmediğini önemseyen bir yaklaşım benimsemiştir. Böylece müellif, manasını doğru bulmasından hareketle, aslı olmayan, mevzû olarak değerlendirilen veya bazı zâhid ve sûfîlere nispet edilen her sözü hadis olarak $\mathrm{Hz}$. Peygamber'e izafe etmiş ve istidlâlde bulunmuştur.

Sünbül Sinân hadis olarak sunduğu söz ve rivayetler üzerinde işârî yorumlarda da bulunmuştur. Ancak o işârî yorumlarında, işârî yorumda aranan kurallara riâyet etmiş, hadislerin zahirî manalarını iptal etmediği gibi, dinin genel ilkelerine aykırı işârî yorumlarda da bulunmamıştır. $\mathrm{O}$, delil olarak sunduğu rivayetlerin ve sözlerin lafızlarından veya işârî anlamlarından hareketle nefis mertebelerini temellendirmeye çalışmıştır. Fakat bu hususta hadis olarak sunduğu naklî delillerin, bilhassa hadis olarak sağlam bir temele dayanmadığı, neredeyse tamamının zayıf, aslı olmayan, ihtilaflı ve problemli söz ve haberlerden oluştuğu müşâhede edilmektedir. Ancak bu hususta risâlede sunulan rivayetlerin durumuna bakarak, tasavvuf ilminde nefis mertebeleri ya da etvâr-1 seb'a olarak insanın kemâl yolculuğunu ifade eden anlayışın hiçbir dinî ve ilmî temelinin bulunmadığı gibi bir sonuca ve kanaata ulaşmak doğru değildir. Zira Kur'ân ve Sünnetin temel hedefi, insanı ahlâken güzelleştirmek, nefsini tezkiye edip, ruhunu yücelterek ve kemâle ulaştırarak, dünya ve âhirette mutluluğa ulaştırmaktır. Tasavvufun temel gayesi de bu hedefe ulaşmada insana yardımcı olmak ve ona rehberlik etmektedir. Sûfîler gibi Sünbül Sinan'ın da hadis kullanımında bu amacı esas aldığı görülmektedir. Onlar tasavvufun amaçları bakımından örtüşen, anlamı kendi öğretileri açısından uygunluk arz eden her söze ehemmiyet vermişler, aslı olmayan, sübut ve sihhat bakımından tenkide uğrayan rivayetleri, $\mathrm{Hz}$. 
42 I M. BAYRAKTUTAR / Halvetiyye Geleneğindeki Nefis Mertebeleri Anlayışının Hadislerdeki Dayanakları (Yusuf Sünbül Sinân'ın Etvâr-ı Seb 'a Risâlesi Özelinde)

Peygamber'e hadis olarak nispet etmekte mütesâhil bir tutum sergilemişlerdir. Oysa bu noktada sûfîlerin tasavvufî öğreti ve anlayışlarını temellendirirken, rivâyetleri değerlendirmede hadis ilminin usûl ve esaslarını dikkate almaları, sübûtu ve sihhati problemli rivayetler yerine sahih ve sabit rivâyetleri tercih eden bir anlayışla hareket etmeleri hiç şüphesiz daha yerinde bir yaklaşım olacaktır. Zira tasavvufun öğretilerini teyit bağlamında yeterince âyet ve shhhati sağlam hadis bulunmakta olup, shhhati problemli rivayetlere ihtiyaç bırakmamaktadır. Sonuç olarak seyr-u sülukte önemli bir yer ifade eden etvâr-1 seb'a anlayışının Kur'an ve Sünnet ekseninde, hadis ilminin yöntem ve verileri dikkat alınarak, sübut ve sıhhat bakımından daha güvenilir rivayetler bağlamında yeniden ele alınarak temellendirilmelidir. $\mathrm{Bu}$ tür yeni araştırma ve çalışmalar, tasavvufa yöneltilecek tenkitlerin azalmasına sebep olabileceği gibi Kur'an ve Sünnet eksenli, sağlam temellere dayalı sahih tasavvuf anlayışının neşvü nemâ bulmasına da ciddi katkılar sunacaktır.

\section{Kaynakça}

Aclûnî, İsmâil b. Muhammed. Keşfu'l-hafâ. 2 Cilt. Kahire: Mektebetu'1Kudsî, 1351.

Ahmed b. Hanbel, Ebû Abdillâh Ahmed b. Muhammed. el-Musned. thk. Şuayb el-Arnaût - Âdil Murşid. 45 Cilt. Beyrut: Muessesetu'rRisâle, 1421/2001.

Akpınar, Cemil. "Huttelî". Türkiye Diyanet Vakfi İslâm Ansiklopedisi. 18/429. İstanbul: TDV Yayınları, 1998.

Âlûsî, Şihâbuddîn Mahmûd. Rûhu'l-maânî. thk. Ali Abdulbârî Atıyye. 16 Cilt. Beyrut: Dâru'l-kutubi'l-ilmiyye, 1415.

Ateş, Süleyman. "Hicâb". Türkiye Diyanet Vakfi İslam Ansiklopedisi. 17/430-431. İstanbul: TDV Yayınları, 1998.

Aydınlı, Abdullah. Doğuş Devrinde Tasavouf ve Hadis. İstanbul: Seha Neşriyat, 1986.

Ayiş, Mehmet Şirin. "Sünbül Sinân ve Atvâr-1 Seb'a Risalesi Bağlaminda Nefis Mertebeleri". Bingöl Üniversitesi Sosyal Bilimler Enstitüsü Dergisi 7/13 (2017), 119-138.

Ayiş, Mehmet Şirin. "Sünbül Sinân'ın İlmî ve Tasavvufî Kişiliği". Uluslararası Amasya Âlimleri Sempozyumu. 1/647-655. Amasya: Kibatek, 2017. 
M. BAYRAKTUTAR / The Hadith-Based Foundations of the Nafs Stages in Khalwatiyya Tradition (In the example of al-Atwar al-Sab'a Epistle Written by Yusuf Sunbul Sinan) I 43

Beyhakî, Ahmed b. el-Huseyn. el-Esmâ ve's-sıfât. thk. A. Muhammed elHâşidî. 2 Cilt. Cidde: Mektebetu's-Sevadî, 1413/1993.

Beyhakî, Ahmed b. el-Huseyn. Şuabu'l-imân. thk. Abdulalî Abdulahmîd. 14 Cilt. Riyad: Mektebetu'r-Ruşd, 1423/2003.

Bezzâr, Ahmed b. Amr. Musned. thk. Mahfûzurrahman Zeynullah vd.. 2 Cilt. Medîne: Mektebetu'l-Ulûm, 2009.

Bîbî, Ummu'l-Fazl Bîbî bnt. Abdussamed. Cuz'u Bîbî. thk. Abdurrahman b. Abdulcebbâr. Kuveyt: Dâru'l-Hulefa, 1986.

Bostanc1, Ali Haydar. Tasavvuf'ta Etvâr-ı Seb 'a ve Sofyalı Bâlî Efendi'nin "Etvâr-ı Seb 'a"sl. İstanbul: Marmara Üniversitesi, Sosyal Bilimler Enstitüsü, Yüksek Lisans Tezi, 1996.

Buhârî, Muhammed b. İsmâîl. el-Câmiu's-sahîh. thk. Muhammed Zuheyr b. Nâsır. 9 Cilt. b.y.: Dâru tavkı'n-necât, 1422/2004.

Bursalı, Mehmed Tahir. Osmanlı Müellifleri. haz. A. Fikri Yavuz - İsmail Özen. 3 Cilt. İstanbul: Meral Yayınevi, ts.

Bursevî, İsmail Hakkı. Kenz-i Mahfí. İstanbul: y.y., 1980.

Bursevî, İsmail Hakkı. Rûhu'l-beyân. Beyrut: Dâru'l-Fikr, ts.

Çelebi, İlyas. "Hicâb". Türkiye Diyanet Vakfı İslam Ansiklopedisi. 17/429430. İstanbul: TDV Yayınları, 1998.

Cuveynî, İmâmu'l-Haremeyn Ruknuddîn. Gryâsu'l-umem fi't-teyyâsi'zzulem. thk. Abdulazîm ed-Dîb. b.y.: el-Mektebâtu'l-Kubrâ, $1401 / 1981$.

Dârimî, Abdullah b. Abdurrahman. Sunen. thk. Huseyn Selim edDârânî. 4 Cilt. Riyâd: Dâru'l-muğnî, 2000.

Dârimî, Osman b. Saîd. er-Red ala'l-Cehmiyye. thk. Bedr b. Abdullah. Kuveyt: Dâru İbni'l-Esîr, 1416/1995.

Deylemî, Şîrûyeh b. Şehrdâr. el-Firdevs bi-me'sûri'l-hitâb. thk. es-Saîd b. Besyûnî. 5 Cilt. Beyrut: Dâru'l-kutubi'l-ilmiyye, 1406/1986.

Dûlâbî, Muhammed b. Ahmed. el-Kunâ ve'l-esmâ. thk. Muhammed elFaryâbî. 3 Cilt. Beyrut: Dâru İbn Hazm, 1421/2000.

Ebû Dâvûd, Suleymân b. el-Eş'as es-Sicistânî. Sunen. thk. M. Muhyiddîn Abdulhamîd. 4 Cilt. Beyrut: el-Mektebetu'l-Asriyye, 1430/2009.

Ebû Nuaym, Ahmed b. Abdullah. Hilyetu'l-evliyâ. 10 Cilt. Misr: Dâru'sSaâde, 1394/1974.

Ebû Ya'lâ, Ahmed b. Alî. Musnedu Ebî Ya'lâ. thk. H. Selîm Esed. 13 Cilt. Dımaşk: Dâru'l-Me'mûn li't-Turâs, 1404/1984. 
44 I M. BAYRAKTUTAR / Halvetiyye Geleneğindeki Nefis Mertebeleri Anlayışının Hadislerdeki Dayanakları (Yusuf Sünbül Sinân'ın Etvâr-ı Seb ‘a Risâlesi Özelinde)

Ebu'ş-Şeyh, Abdullah b. Muhammed. Kitâbu'l-azame. thk. Rıdâullah b. Muhammed. 5 Cilt. Riyâd: Dâru'l-Âsıme, 1408.

Ebu'ş-Şeyh, Abdullah b. Muhammed. Emsâlu'l-hadîs. thk. Abdulalî Abdulhamîd. Bombay: ed-Dâru's-Selefiyye, 1408/1987.

Ebu'ş-Şeyh, Abdullah b. Muhammed. et-Tevbîh ve't-Tenbîh. thk. Mecdî es-Seyyid İbrâhim. Kahire: Mektebetu'l-Furkan, ts.

Elbânî, Nâsıruddîn. Silsiletu'l-ehâdisi'z-zaîfe ve'l-mevzûa. 14 Cilt. Beyrut: Dâru'l-Maârif, 1412/1992.

Erul, Bünyamin. "Uydurma Rivâyetlerde Peygamber Tasavvuru". İslâm'ın Anlaşılmasında Sünnetin Yeri ve Değeri Sempozyumu. 419435. Ankara: TDV Yayınları, 2001.

Ezdî, Muhammed b. el-Huseyn. el-Mahzûn fî ilmi'l-hadîs. thk. M. İkbal Muhammed. Delhi: ed-Dâru'l-ilmiyye, 1408/1988.

Fettenî, Cemâluddîn Muhammed Tâhir. Tezkiretu'l-mevzûât. b.y.: İdâretu't-Tibâa'ti'l-Munîre, ts.

Gazzâlî, Ebû Hâmid Muhammed. İhyâu ulûmi'd-dîn. Beyrut: Dâru'1Ma'rife, ts.

Gazzâlî, Ebû Hâmid Muhammed. Mizânu'l-amel. thk. Suleyman Dunyâ. 4 Cilt. Misır: Dâru'l-Maârif, 1964.

Hakîm et-Tirmizî, Muhammed b. Ali. el-Emsâl mine'l-Kitab ve's-sunne. thk. es-Seyyid el-Cemîlî. Beyrut: Dâru İbn Zeydûn, ts.

Hakîm et-Tirmizî, Muhammed b. Ali. Nevâdiru'l-usûl. thk. Abdurrahman Umeyra. 4 Cilt. Beyrut: Dâru'l-Ciyl, 1992.

Haksever, Ahmed Cahid. Tasavvufu Anlama Klavuzu. Ankara: Otto Yayınları, 2017.

Hatîb el-Bağdâdî, Ahmed b. Alî. el-Câmi' li-ahlâki'r-râvî. thk. Mahmûd Tahhân. 2 Cilt. Riyâd: Mektebetu'l-Maârif, 1403/1983.

Hatîb el-Bağdâdî, Ahmed b. Alî. Mûdıhu evhâmi'l-cem ve't-tefrîk. thk. A. Emîn Kal'acî. 2 Cilt. Beyrut: Dâru'l-Ma'rife, 1407/1986.

Hatîb el-Bağdâdî, Ahmed b. Alî. Tarîhu Bağdâd. thk. Beşşâr Avvâd Ma'rûf. 16 Cilt. Beyrut: Dâru'l-Garbi'l-İslâmî, 1422/2002.

Havvâ, Saîd. el-Esâs fi't-tefsîr. 11 Cilt. Kahire: Dâru's-selâm, 1424/2003.

Hût, Muhammed Dervîş. Esne'l-metâlib. thk. M. Abdulkâdir Atâ. Beyrut: Dâru'l-kutubi'l-ilmiyye, 1418/1997.

Huttelî, İbrahim b. Abdullah. el-Muhabbetu lillâhi Subhânehu. thk. Abdullah Bedrân. Dımaşk: Dâru'l-Mektebî, 1423/2000. 
M. BAYRAKTUTAR / The Hadith-Based Foundations of the Nafs Stages in Khalwatiyya Tradition (In the example of al-Atwar al-Sab'a Epistle Written by Yusuf Sunbul Sinan) I 45

İbn Adî, Ebû Ahmed b. Adî el-Curcânî. el-Kâmil fî duafâi'r-ricâl. thk. Âdil Ahmed Abdulmevcûd. 9 Cilt. Beyrût: Dâru'l-kutubi'l-ilmiyye, 1418/1997.

İbn Arrâk, Ebu'l-Hasen Nûruddîn. Tenzîhu'ş-şerîa. thk. Abdulvahhâb Abdullatif-Sıddık el-Gumârî. 2 Cilt. Beyrut: Dâru'l-kutubi'lilmiyye, 1399.

İbn Asâkir, Ali b. el-Hasen. Târihu Dımaşk. thk. Amr b. Garâme. 80 Cilt. Beyrut: Dâru'l-Fikr, 1415/1995.

İbn Ebî Âsım, Ahmed b. Amr. Kitâbu's-sunne. thk. Nâsıruddîn el-Elbânî. 2 Cilt. el-Mektebu'l-İslâmî, 1400/1980.

İbn Ebî Hayseme, Ebû Bekr Ahmed. et-Târîhu'l-kebîr. thk. Salâh b. Fethî. 2 Cilt. Kahire: el-Fâruku'l-Hadîse, 1425/2006.

İbn Ebi'd-Dunyâ, Abdullah b. Muhammed. Islâhu'l-mâl. thk. M. Abdulkadir Atâ. Beyrût: Muessesetu'l-kutubi's-sikâfiyye, 1414/1981.

İbn Hacer, Ahmed b. Alî el-Askalânî. el-Metâlibu'l-âliye. 19 Cilt. Riyad: Dâru'l-Âsıme, 1420/2000.

İbn Hacer, Ahmed b. Alî el-Askalânî. et-Telhîsu'l-habîr. thk. Hasen b. Abbâs. 4 Cilt. Misır: Muessesetu Kurtuba, 1416/1996.

İbn Hacer, Ahmed b. Alî el-Askalânî. Fethu'l-Bârî. 13 Cilt. Beyrut: Dâru'lMa'rife, 1379.

İbn Hacer, Ahmed b. Alî el-Askalânî. İthâfu'l-hıyereti'l-mehere. thk. Ebu Temîm Yasir. 9 Cilt. Riyad: Dâru'l-Vatan, 1420/1999.

İbn Hacer, Ahmed b. Alî el-Askalânî. Lisânu'l-Mizân. thk. Abdulfettâh Ebû Gudde. 10 Cilt. b.y.: Dâru'l-Beşâiri'l-İslâmiyye, 2002.

İbn Huzeyme, Muhammed b. İshâk. Kitâbu't-tevhîd. thk. Abdulazîz b. İbrahim. 2 Cilt. Riyâd: Mektebetu'r-Ruşd, 1414/1994.

İbn Mâce, Muhammed b. Yezîd. Sunen. thk. Şuayb el-Arnaût-Kâmil Karabellî. 5 Cilt. b.y.: Dâru'r-Risâle, 1430/2009.

İbn Manzûr, Muhammed b. Mukrim. Muhtasaru Târîhi Dımaşk li-İbn Asâkir. 29 Cilt. Dimaşk: Dâru'l-Fikr, 1402/1984.

İbn Teymiyye, Takıyyuddîn Ahmed. el-Fetâva'l-kubrâ. thk. M. Abdulkadir Atâ. 6 Cilt. Beyrut: Dâru'l-kutubi'l-ilmiyye, 1408/1987.

İbn Teymiyye, Takıyyuddîn Ahmed. Mecmû'ul-fetâvâ. thk. Abdurrahman b. Muhammed. 35 Cilt. Medîne: Mecmau'l-Melik Fahd, 1416/1996. 
46 I M. BAYRAKTUTAR / Halvetiyye Geleneğindeki Nefis Mertebeleri Anlayışının Hadislerdeki Dayanakları (Yusuf Sünbül Sinân'ın Etvâr-ı Seb 'a Risâlesi Özelinde)

İbnu'l-A'râbî, Ahmed b. Muhammed. Mu'cemu İbni'l-A'râbî. thk. Abdulmuhsin el-Huseynî. 3 Cilt. Suûdiyye: Dâru İbni'l-Cevzî, 1418/1998.

İbnu'l-Cevzî, Cemâluddîn Abdurrahman. el-ílelu'l-mutenâhiye. thk. İrşâdulhak el-Eserî. 2 Cilt. Faysalâbâd: İdâretu'l-Ulûmi'l-Eseriyye, 1401/1981.

İbnu'l-Cevzî, Cemâluddîn Abdurrahman. el-Mevzûât. thk. A. Muhammed Muhsin. 3 Cilt. Medîne: el-Mektebetu's-Selefiyye, 1388/1968.

İbnu'l-Fârız, Şerefuddîn Ömer. Dîvânu İbni'l-Fârız. Beyrut: Dâru Sâdır, ts.

İbnu'l-Imâd, Abdulhayy b. Ahmed. Şezerâtu'z-zeheb. thk. Mahmûd elArnaût. 11 Cilt. Dimaşk: Dâru İbn Kesir, 1406/1986.

İbnu'l-Mubârek, Ebu Abdurrahman Abdullah b. el-Mubârek. el-Cihâd. thk. Nezîh Hammâd. Tunus: ed-Dâru't-Tunûsiyye, 1972.

Irâkî, Zeynuddîn Abdurrahim. Tahrîcu ehâdîsi İhyâi ulûmi'd-dîn. 7 Cilt. Riyâd: Dâru'l-Âsıme, 1408/1987.

Işıtan, İbrahim. "Halvetiyye Geleneğine ve Bir Halvetiyye Şeyhi Olan Sofyalı Bâlî Efendi'ye Göre Sülûkün Yedi Evresi (Atvâr-1 Seb'a)". Hikmet Yurdu 4/7 (2011), 89-113.

Işıtan, İbrahim. “Dergâhlarda Zâhir-Bâtın Bilgi Dengesinin Sûfî Şahsiyet Gelişimine Katkısı ve Şeyh Şâbân-1 Velî Örneği". III. Uluslararası Şeyh Şa'bân-ı Velî Sempozyumu, ed. Ali Rafet Özkan. 367-376. Kastamonu: Kastamonu Üniversitesi Yayınları, 2016.

Kalaycı, Mehmet. "Kadıâdeliler-Halvetîler Geriliminin Odağında Bir İsim: Sünbül Sinân el-Amâsî ve er-Risâletu't-Tahkîkiyye Adlı Eseri". Uluslararası Amasya Alimleri Sempozyumu. 1/601-611. Amasya: Kıbatek, 2017.

Karâfî, Şihâbuddîn Ahmed. el-Furûk. 4 Cilt. b.y.: Âlemu'l-kutub, ts.

Karapınar, Fikret. "Rivayetlerde İşârî Yorum". Hadis Tetkikleri Dergisi 5/2 (2007), 89-104.

Kârî, Nûruddîn Ali. Mirkâtu'l-mefâtîh. 9 Cilt. Beyrut: Dâru'l-Fikr, $1422 / 2002$.

Kârî, Nûruddîn Ali. el-Masnû'. thk. Abdulfettah Ebû Gudde. b.y.: Mektebu'l-Matbûâti'l-İslamiyye, ts.

Kelâbâzî, Muhammed b. Ebî İshâk. Bahru'l-fevâid. thk. Muhammed Hasen - Ahmed Ferîd. Beyrût: Dâru'l-kutubi'l-ilmiyye, 1420/1999. 
M. BAYRAKTUTAR / The Hadith-Based Foundations of the Nafs Stages in Khalwatiyya Tradition (In the example of al-Atwar al-Sab'a Epistle Written by Yusuf Sunbul Sinan) I 47

Köktaş, Yavuz. İlk Dönem Sûfîleri ve Hadis Hakîm et-Tirmizî Örneği. İstanbul: Gelenek Yayınları, 2010.

Kudâî, Muhammed b. Selâme. Musnedu'ş-Şihâb. thk. Hamdî b. Abdulmecîd. 2 Cilt. Beyrut: Muessesetu'r-Risâle, 1407/1986.

Küey, Emrehan. "Merkez Efendi ve Sünbül Sinân". Bursa'da Dünden Bugüne Tasavvuf Kültürü-3. haz. H. Basri Öcalan. Bursa: Bursa Kültür Sanat Vakfı Yayınları, 2014.

Kuşeyrî, Abdulkerîm b. Hevâzin. er-Risâletu'l-Kuşeyriyye. thk. Abdulhalim Mahmûd - Mahmud b. eş-Şerîf. 2 Cilt. Kahire: Dâru'lMaârif, ts.

Muhâsibî, Ebû Abdillah el-Hâris b. Esed. er-Riâye li hukûkillâh. thk. Abdulkadîr Ahmed Atâ. Beyrut: Dâru'l-kutubi'l-ilmiyye, ts.

Munâvî, Zeynuddîn Abdurraûf. et-Teysîr bi-şerhi'l-Câmi'i's-sağîr. 2 Cilt. Riyâd: Mektebetu'l-İmami'ş-Şâfi'î, 1408/1988.

Munâvî, Zeynuddîn Abdurraûf. Feyzu'l-kadîr. 6 Cilt. Misır: elMektebetu't-Ticâriyyeti'l-Kubrâ, 1356.

Muslim, Ebu'l-Huseyn Muslim b. el-Haccâc. el-Musnedu's-sahîh. thk. M. Fuâd Abdulbâkî. 5 Cilt. Beyrût: Dâru İhyâi't-Turâsi'l-Arabî, ts.

Nesâî, Ahmed b. Şuayb. Sunen. thk. Abdulfettâh Ebû Gudde. 9 Cilt. Haleb: Mektebetu'1-Matbûâti'1-İslâmiyye, 1406/1986.

Nevevî, Yahyâ b. Şeref. Fetâvâyı'l-Imami'n-Nevevî. thk. Muhammed elHaccâr. Beyrût: Dâru'l-Beşâir, 1417/1996.

Râzî, Fahruddîn Muhammed. Mefâtîhu'l-gayb. 32 Cilt. Beyrut: Dâru İhyai't-Turâsi'l-Arabî, 1420.

Rûyânî, Ebu Bekr Muhammed b. Hârûn. Musnedu'r-Rûyânî. thk. Eymen Alî. 2 Cilt. Kahire: Muessesetu Kurtuba, 1416.

Sağânî, Radiyyuddîn el-Hasen. el-Mevzĥât. thk. N. Abdurrahman Halef. Dımaşk: Dâru'l-Me'mûn, 1405/1984.

Saîd b. Mansûr, Ebu Osmân. Sunen. thk. Habiburrahman el-A'zamî. 2 Cilt. Hindistan: ed-Dâru's-Selefiyye, 1403/1982.

Seccâdî, Seyyid Cafer. Tasavvuf ve İrfan Terimleri Sözlü̈̆̈̈̈. çev. Hakkı Uygur. İstanbul: Ensar Neşriyat, 2007.

Sehâranpûrî, Halil Ahmed. Bezlû'l-mechûd. 14 Cilt. Hindistan: Merkezu'ş-Şeyh Ebi'l-Hasen en-Nedevî, 1427/2006.

Sehâvî, Şemsuddîn Muhammed. el-Ecvibetu'l-murdiyye. 3 Cilt. thk. Muhammed İshâk. b.y.: Dâru'r-Râye, 1418/1997. 
48 I M. BAYRAKTUTAR / Halvetiyye Geleneğindeki Nefis Mertebeleri Anlayışının Hadislerdeki Dayanakları (Yusuf Sünbül Sinân'ın Etvâr-ı Seb ‘a Risâlesi Özelinde)

Sehâvî, el-Makâsıdu'l-hasene. thk. M. Osmân el-Hışt. Beyrut: Dâru'lKutubi'l-Arabî, 1405/1985.

Semerkandî, Ebu'l-Leys Nasr. Tenbîhu'l-gâfilîn. thk. Yusuf Ali Bedeyvî. Dımaşk: Dâru İbn Kesîr, 1421/2000.

Serahsî, Muhammed b. Ebî Sehl. Şerhu's-Siyeri'l-kebîr. 5 Cilt. b.y.: eşŞeriketu'ş-Şarkiyye, 1971.

Serrâc, Ebû Nasr et-Tûsî. el-Luma'. thk. Abdulhalîm Mahmûd Abdulbâkî Surûr. Misr: Dâru'l-Kutubi'l-Hadîse, 1380/1960.

Şevkânî, Muhammed b. Alî. el-Fevâiidu'l-mecmûa. thk. Abdurrahman elMuallimî. Riyad: Dâru'l-kutubi'l-ilmiyye, ts.

Sinân, Yakub Sünbül. Risâletun Şerîfetun fi Beyâni Etvâri's-Seb'ati fi Tarîkati't-Tasavvufi ve'z-Zuhd. Tarihi: 1244, Milli Kütüphane Yazmalar Koleksiyonu, DVD No: 1788, Arşiv No: 06 Mil Yz A $8942 / 2,14 a-22 b$.

Sulemî, Muhammed b. el-Huseyn. Hakâiku't-tefsîr. thk. Seyyid Amrân. Beyrut: Dâru'l-kutubi'l-ilmiyye, 1421/2001.

Sulemî, Muhammed b. el-Huseyn. Âdâbu's-suhbe. thk. M. Fethî esSeyyid. Tantâ: Dâru's-sahâbe li't-turâs, 1410/1990.

Suyûtî, Celâluddîn Abdurrahman. ed-Dureru'l-muntesira fi'l-ehâdîsi'lmuştehira. thk. M. Lutfi es-Sabbâğ. Riyad: Camiatu'l-Melik Suud, ts.

Suyûtî, Celâluddîn Abdurrahman. ed-Dîbâc alâ Sahîh-i Muslim b. elHaccâc. thk. Ebû İshak el-Huveynî Suûdiyye: Dâru İbn Affân, 1416/1996.

Suyûtî, Celâluddîn Abdurrahman. el-Leâliu'l-masnûa. 2 Cilt: Beyrut: Dâru'l-kutubi'l-ilmiyye, 1414/1996.

Suyûtî, Celâluddîn Abdurrahman. Tedrîbu'r-râvî. 2 Cilt. thk. Ebu Kuteybe el-Fâdyâbî. Riyad: Mektebetu'l-Kevser, 1415/1995.

Taberânî, Suleyman b. Ahmed. el-Mu'cemu'l-evsat. 10 Cilt. thk. Tarık Ivadullah - Abdulmuhsin b. İbrahim. Kahire: Dâru'l-Harameyn, ts. Taberânî, Suleyman b. Ahmed. el-Mu'cemu'l-kebîr. thk. Hamdî Abdulmecîd. 25 Cilt. Kahire: Mektebetu İbn Teymiyye, 1415/1993.

Tayâlisî, Ebû Dâvûd Suleymân b. Dâvud. Musned. thk. M. Abdulmuhsin et-Turkî. 4 Cilt. Misır: Dâru Hicr, 1419/1999.

Tayşî, Mehmet Serhan. "Cemâl-i Halvetî". Türkiye Diyanet Vakfı İslam Ansiklopedisi. 7/302-3003. İstanbul: TDV Yayınları, 1993. 
M. BAYRAKTUTAR / The Hadith-Based Foundations of the Nafs Stages in Khalwatiyya Tradition (In the example of al-Atwar al-Sab'a Epistle Written by Yusuf Sunbul Sinan) I 49

Teymî, İsmâil b. Muhammed. et-Tergî̉b ve't-terhîb. thk. Eymen b. Sâlih. Kahire: Dâru'l-Hadîs, 1414/1993.

Tirmizî, Muhammed b. İsâ. Sunen. thk. Beşşâr Avvâd. 6 Cilt. Beyrut: Dâru'l-Garbi'l-İslâmî, 1998.

Türer, Osman. Tasavouf Tarihi. İstanbul: Seha Neşriyat, ts.

Tusterî, Sehl b. Abdullah. Tefsîru't-Tusterî. thk. Muhammed Bâsil. Beyrut: Dâru'l-kutubi'l-ilmiyye, 1423/2002.

Tuyûrî, el-Mubârek b. Abdulcebbâr. et-Tuyûriyyât. thk. Abbas Sahr. 4 Cilt. Riyâd: Mektebetu Edvâi's-Selef, 1425/2004.

Ukaylî, Ebu Cafer Muhammed b. Amr. ed-Duafâu'l-kebîr. thk. A. Emîn Kal'acî. 4 Cilt. Beyrut: Dâru'l-kutubi'l-ilmiyye, 1404/1984.

Uludağ, Süleyman. "Fakr". Türkiye Diyanet Vakfi İslam Ansiklopedisi. 12/132-134. İstanbul: TDV Yayınları, 1995.

Uludağ, Süleyman. "Nefis". Türkiye Diyanet Vakfi İslam Ansiklopedisi. 32/526-529. İstanbul: TDV Yayınlar1, 2006.

Uysal, Muhittin. Tasavouf Kültüründe Hadis. İstanbul: Ensar Yayınları, 2002.

Vassâf, Osmanzâde Huseyin. Sefine-i Evliyâ. haz. Mehmet Akkuş - Ali Yılmaz. İstanbul: Kitabevi Yayınları, 2015.

Yıldırım, Ahmet. "Tasavvufun Kaynağı Olarak Hadis". Hadis ve Siyer Araştırmaları Dergisi 4/2 (2018), 51-70.

Yıldırım, Ahmet. Tasavvufun Temel Öğretilerinin Hadislerdeki Dayanakları. Ankara: TDV Yayınları, 2013.

Yıldırım, Ahmet. Hoca Ahmed Yesevî'nin Hadis Kültürü. Ankara: TDV Yayınları, 2012.

Yıldırım, Ahmet. "Hadisleri Anlamada İşârî Yorum". Süleyman Demirel Üniversitesi Illahiyat Fakültesi Dergisi 13 (2004), 13-36.

Yıldız, Fatih. Halvetî Azizlerinin Etvâr-ı Seb'a Risâleleri. İstanbul: Büyüyenay Yayınları, 2019.

Yücer, Hür Mahmut. "Sünbül Sinân". Türkiye Diyanet Vakfı İslam Ansiklopedisi. 38/135-136. Ankara: TDV Yayınları, 2010.

Zehebî, Şemsuddîn Muhammed. Mîzânu'l-i'tidâl. thk. Alî Muhammed elBicâvî. 4 Cilt. Beyrut: Dâru'l-Ma'rife, 1382/1963.

Zehebî, Şemsuddîn Muhammed. Siyeru a'lâmi'n-nubelâ. 18 Cilt. Kahire: Dâru'l-Hadîs, 1427/2006. 
50 | M. BAYRAKTUTAR / Halvetiyye Geleneğindeki Nefis Mertebeleri Anlayışının Hadislerdeki Dayanakları (Yusuf Sünbül Sinân'ın Etvâr-ı Seb 'a Risâlesi Özelinde)

Zerkeşî, Bedrûddîn Muhammed. el-Leâliu'l-mensûra fi'l-ehâdîsi'l-meşhûra. thk. M. Abdulkadir Atâ. Beyrut: Dâru'l-kutubi'l-ilmiyye, 1406/1986. 